\section{Pacific Northwest}

National Laboratory

Operated by Battelle for the

U.S. Department of Energy

\title{
Geographic and Operational Site Parameters List (GOSPL) for the 2004 Composite Analysis
}

\author{
G. V. Last \\ W. E. Nichols \\ C. T. Kincaid
}

July 2004

Prepared for the U.S. Department of Energy under Contract DE-AC06-76RL01830 


\title{
DISCLAIMER
}

This report was prepared as an account of work sponsored by an agency of the United States Government. Neither the United States Government nor any agency thereof, nor Battelle Memorial Institute, nor any of their employees, makes any warranty, express or implied, or assumes any legal liability or responsibility for the accuracy, completeness, or usefulness of any information, apparatus, product, or process disclosed, or represents that its use would not infringe privately owned rights. Reference herein to any specific commercial product, process, or service by trade name, trademark, manufacturer, or otherwise does not necessarily constitute or imply its endorsement, recommendation, or favoring by the United States Government or any agency thereof, or Battelle Memorial Institute. The views and opinions of authors expressed herein do not necessarily state or reflect those of the United States Government or any agency thereof.

\author{
PACIFIC NORTHWEST NATIONAL LABORATORY \\ operated by \\ BATTELLE \\ for the \\ UNITED STATES DEPARTMENT OF ENERGY \\ under Contract DE-AC06-76RL01830
}

Printed in the United States of America
Available to DOE and DOE contractors from the Office of Scientific and Technical Information,
P.O. Box 62, Oak Ridge, TN 37831-0062;
ph: (865) 576-8401
fax: (865) 576-5728
email: reports@adonis.osti.gov

\author{
Available to the public from the National Technical Information Service, \\ U.S. Department of Commerce, 5285 Port Royal Rd., Springfield, VA 22161 \\ ph: (800) 553-6847 \\ fax: (703) 605-6900 \\ email: orders@ntis.fedworld.gov \\ online ordering: http://www.ntis.gov/ordering.htm
}

This document was printed on recycled paper. 


\title{
Geographic and Operational Site Parameters List (GOSPL) for the 2004 Composite Analysis
}

\author{
G. V. Last \\ W. E. Nichols \\ C. T. Kincaid
}

July 2004

Prepared for

the U.S. Department of Energy

under Contract DE-AC06-76RL01830

Pacific Northwest National Laboratory

Richland, Washington 99352 


\section{Executive Summary}

A composite analysis is required by U.S. Department of Energy (DOE) Order 435.1 to ensure public safety through the management of active and planned low-level radioactive waste disposal facilities associated with the Hanford Site. Kincaid et al. (2004) indicated that the System Assessment Capability (SAC) (Kincaid et al. 2000; Bryce et al. 2002; Eslinger 2002a, 2002b) would be used to analyze over a thousand different waste sites.

A master spreadsheet termed the Geographic and Operational Site Parameters List (GOSPL) was assembled to facilitate the generation of keyword input files containing general information on each waste site, its operational/disposal history, and its environmental settings (past, current, and future). This report briefly describes each of the key data fields, including the source(s) of data, and provides the resulting inputs to be used for the 2004 Composite Analysis. 


\section{Contents}

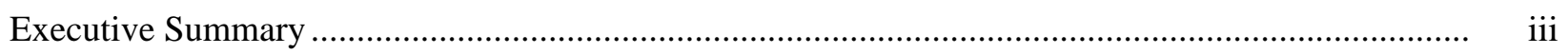

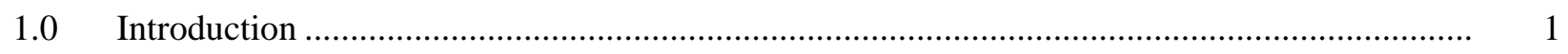

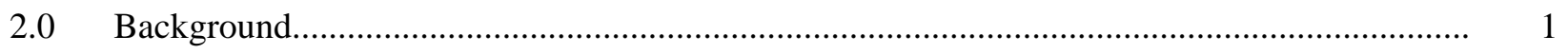

3.0 Geographic and Operational Site Parameter List Definitions ............................................. 6

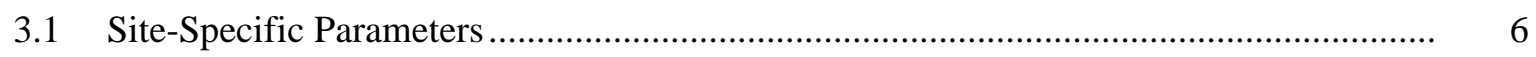

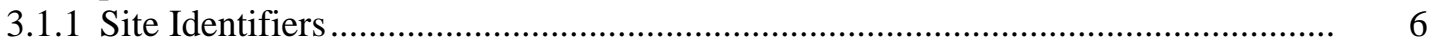

3.1.2 General Site Design and Operational History Information ..................................... 7

3.1.3 Geographic Information ..................................................................................... 8

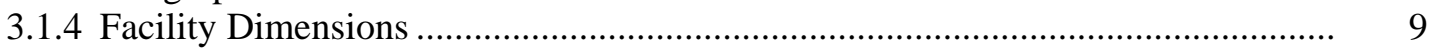

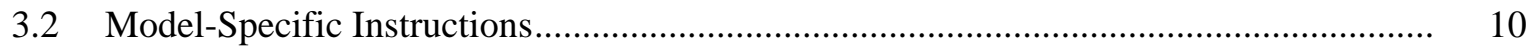

3.2.1 Selected for Simulation in the 2004 Composite Analysis..................................... 10

3.2.2 Release Model Designation .............................................................................. 10

3.2.3 Vadose Zone Model Hydrostratigraphy .................................................................. 11

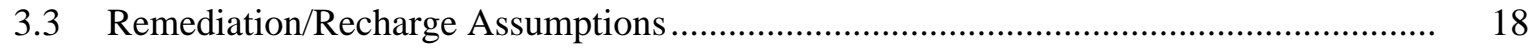

3.3.1 Pre-Hanford Recharge Class ................................................................................ 19

3.3.2 Operational Recharge Class ............................................................................ 19

3.3.3 Interim Remedial Actions .......................................................................... 20

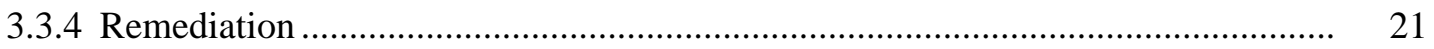

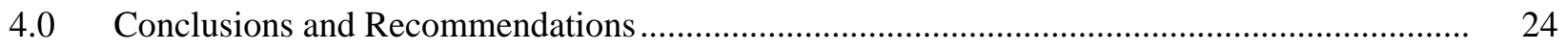

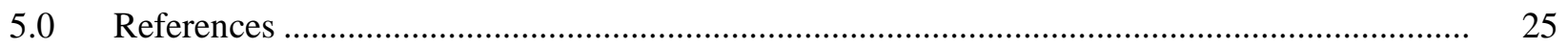

Appendix - Geographic and Operational Site Parameters for Waste Sites To Be Simulated in the 2004 Composite Analysis.................................................................................... A.1

\section{Figures}

2.1 Conceptual Model of the System Assessment Capability .................................................. 3

2.2 Information Flow in SAC Rev. 1 Software Design ............................................................

3.1 Geographic Areas Used to Define Different Hydrostratigraphic Profiles ............................... 14 


\section{Tables}

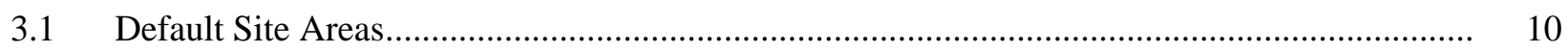

3.2 Summary of Release Model Assignments to Waste Source Types ......................................... 11

3.3 Site Type Codes Used in the Hydrostratigraphic Templates ................................................. 12

3.4 Geographic Area Designations Used in the Hydrostratigraphic Template Codes.................... 15

3.5 Site-Specific Area Designations Used in the Hydrostratigraphic Template Codes................... 15

3.6 Waste Chemistry Groups Used in the Base Template Codes.............................................. 16

3.7 General Hydrostratigraphic Templates for Each Geographic Area ....................................... 16

3.8 Site-Specific Templates Established for a Few Key Facilities ................................................ 18

3.9 Pre-Hanford Recharge Classes for the 2004 Composite Analysis ........................................ 19

3.10 Operational Recharge Classes for the 2004 Composite Analysis......................................... 20

3.11 Example of Interim Remedial Actions Defined for the 2004 Composite Analysis................... 21

3.12 Post-Remediation Recharge Classes ................................................................................ 23

3.13 Post-Remediation/Barrier Design Life ................................................................................. 24 


\subsection{Introduction}

A composite analysis is required by U.S. Department of Energy (DOE) Order 435.1 to ensure public safety through the management of active and planned low-level radioactive waste disposal facilities associated with the Hanford Site. The original composite analysis detailed in Kincaid et al. (1998) must be revised and submitted to DOE Headquarters (DOE-HQ) because of revisions to waste site information in the 100, 200, and 300 Areas; updated performance assessments and environmental impact statements (EIS); changes in inventory estimates for key sites and constituents; and a change in the definition of offsite receptors.

Kincaid et al. (2004) describe the technical scope of the 2004 Composite Analysis for the Hanford Site and the approach to perform this analysis. It will be a site-wide analysis, considering final remedial actions for the Columbia River corridor and the Central Plateau, and will support waste-specific and sitespecific assessments throughout the Hanford Site. The 2004 Composite Analysis also will provide supporting information on a regional or site-wide basis for use in important Hanford assessments and decisions such as the Comprehensive Environmental Response, Compensation, and Liability Act (CERCLA) 5-year review in 2005, tank closure decisions, decisions on final groundwater remedies for the 200 Areas, decisions on final groundwater remedies for the 100 Areas, and the Columbia River corridor final record of decision.

Kincaid et al. (2004) identified 1,046 waste sites from the 2,730 Waste Information Data System (WIDS) sites and several existing and future storage sites for inclusion in the 2004 Composite Analysis. ${ }^{\text {(a) }}$ Each of these sites will be modeled as an individual release or storage site whenever inventory and release data permit. Beginning in fiscal year (FY) 2003, the DOE Richland Operations Office (DOE-RL) initiated activities to develop the input data needed to support the 2004 Composite Analysis. This report describes the compilation of site-specific parameters for incorporation into the Geographic and Operational Site Parameters List (GOSPL) to support the 2004 Composite Analysis. This work was conducted as part of the Characterization of Systems Task of the Groundwater Remediation Project (formerly the Groundwater Protection Program) managed by Fluor Hanford, Inc., Richland, Washington.

\subsection{Background}

Kincaid et al. (2004) indicated that the System Assessment Capability (SAC) (Kincaid et al. 2000; Bryce et al. 2002; Eslinger 2002a, 2002b) would be used for the analysis. The SAC is a set of models and data that have been assembled since the previous 1998 Composite Analysis (Kincaid et al. 1998) was

(a) Originally 974 of 2,730 Waste Information Data System (WIDS) sites were identified for inclusion in the 2004 Composite Analysis. Further work identified 48 more waste sites bringing the total to 1,022. Subsequent reviews identified an additional 24 sites that have been included, many of which account for offsite transfers of waste and nuclear material. This brings the total to 1,046. 
performed to estimate the collective impact of all the waste that will remain at the Hanford Site. Computer codes that have been well tested at the Hanford Site have been used when possible and new software has been written when necessary to simulate the features and processes that affect the release of contaminants into the environment, transport of contaminants through the environment, and the impact those contaminants have on living systems, cultures, and the local economy. The various SAC components have been organized to simulate the transport and fate of contaminants from their presence in Hanford waste sites, through their release into the vadose zone, to their movement in the groundwater, and into the Columbia River. Components of SAC such as the groundwater model, the ecological impact component, and the human health component were originally developed and tested for previous Hanford assessments.

The elements of the SAC computational tool include:

- Inventory Module - develops an inventory of specific waste disposal and storage locations for the period 1944 to Hanford Site closure based on disposal records, process knowledge, the results of tank and field samples, and planned disposals and remedial actions. The year 2035 is used as the Hanford Site closure date for the 2004 Composite Analysis because it has been identified as the time of site closure for the majority of facilities (e.g., tanks, solid waste burial grounds, chemical separations plants). However, the commercial waste site (US Ecology) is assumed to close in 2056 and the graphite cores of the production reactors are moved to the Central Plateau in 2056. Future runs will use the closure date predicted at the time of the run. This module also identifies the material scheduled for disposal in offsite repositories, including high-level waste, transuranic waste, and spent fuel.

- Release Module - simulates the annual release of contaminants to the vadose zone from the variety of waste types in the modeled waste sites. This module also simulates future remediation actions that move waste to the Environmental Restoration Disposal Facility (ERDF) and other permanent disposal locations.

- Air Transport Module - simulates the transport of contaminants through the air pathway from release points to points of deposition.

- Vadose Zone Transport Module - simulates fluid flow and contaminant transport in the vadose zone, which is the unsaturated sediment between the land surface and the unconfined aquifer. The module also simulates the release of volatile contaminants out of the vadose zone into the air pathway.

- Groundwater Transport Module - simulates fluid flow and contaminant transport in the unconfined aquifer that underlies the Hanford Site using the transient inverse calibrated three-dimensional Sitewide groundwater model.

- Soil Module - simulates the buildup of contaminants in the plant root-zone soil layer due to air deposition and irrigation. Solutions are available for the cases of no irrigation, irrigation with groundwater, and irrigation with river water.

- River Module - simulates river flow and contaminant/sediment transport in the Hanford Reach from Vernita Bridge downstream to the city of Richland. This module simulates background concentra- 
tions and background plus the Hanford Site concentrations to enable an assessment of the Hanford Site incremental impact to the Columbia River and its ecosystem.

- Riparian Zone Module - uses river and groundwater information to simulate the concentration of contaminants in seep or spring water and in the wet soil near the edge of the Columbia River.

- Risk/Impact Modules - performs risk/impact analysis in four topical areas: human health, ecological health, economic impact, and cultural impact with the latter two being new impact metrics for Hanford assessments. The ecological and human health risk modules will be applied in the 2004 Composite Analysis. The remaining two modules of risk/impact will be applied in a supplemental analysis to inform the public and regulators regarding issues related to the composite analysis (for example, the economic and cultural impacts of chemical hazards).

Each module was assembled so that it could be tested and evaluated independently of the other modules. The inventory, release, environmental pathways, and risk/impact modules were then linked to test the overall performance of the system.

A conceptual illustration of SAC (Figure 2.1) portrays a linear flow of information. In general, inventory feeds release mechanisms, which feed to the atmospheric, vadose zone, groundwater, and Columbia River pathways. At times, release occurs directly to the groundwater through reverse wells and to the Columbia River from the single-pass reactors. During chemical separation plant operation, release also occurred to the atmosphere. The atmosphere, groundwater, Columbia River, riparian zone and soil technical modules provide media-specific concentration estimates used in the risk and impact assessment.

\section{System Assessment Capability Conceptual Model}

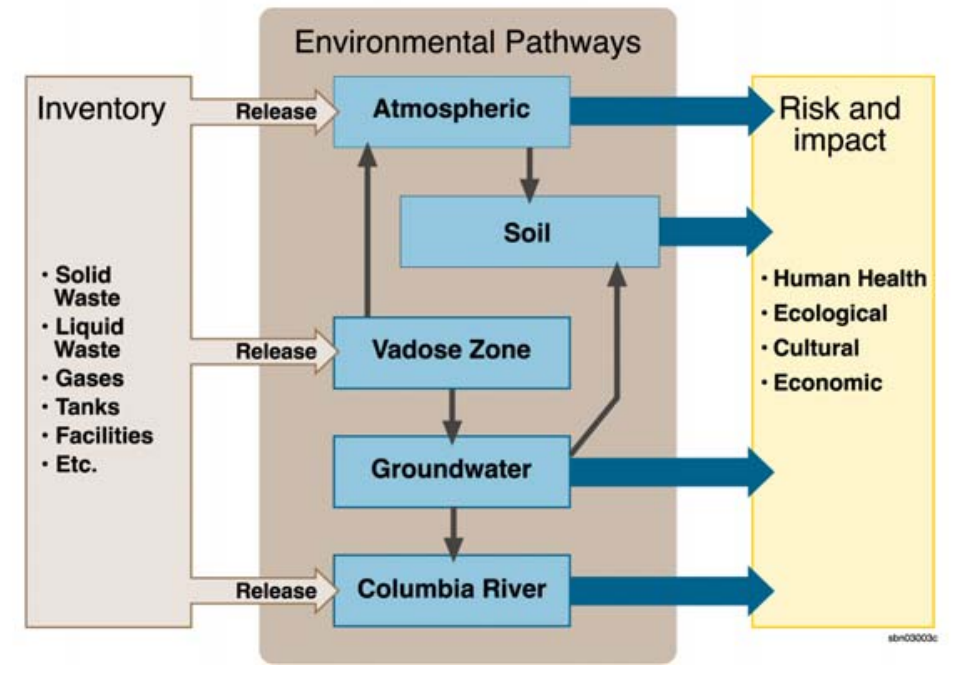

Figure 2.1. Conceptual Model of the System Assessment Capability

Background information for the development of the initial SAC is presented in Groundwater/Vadose Zone Integration Project: Preliminary System Assessment Capability Concepts for Architecture, 
Platform and Data Management. ${ }^{(a)}$ This document includes a description of alternate architectures for SAC as well as conceptual models for each technical element of the capability. Design of the initial SAC tool is summarized in Kincaid et al. (2000). Results of an initial assessment performed with the SAC are provided in Bryce et al. (2002).

A description of the software is provided in Eslinger et al. (2002a, 2002b). The system of codes includes existing computer programs, new computer programs, electronic data libraries, and data formatting processors (or data translators). The relationships among code modules that make up the SAC Systems Code are illustrated in Figure 2.2. Major modules appearing on the left side of the diagram perform inventory and transport calculations providing estimates of the concentrations of analytes in various media. Modules shown on the right perform calculations related to the impact from the contaminated media. Impacts include potential effects on humans, the ecology of the area, the economy of the region, and the proximity of contaminants to social and cultural resources.

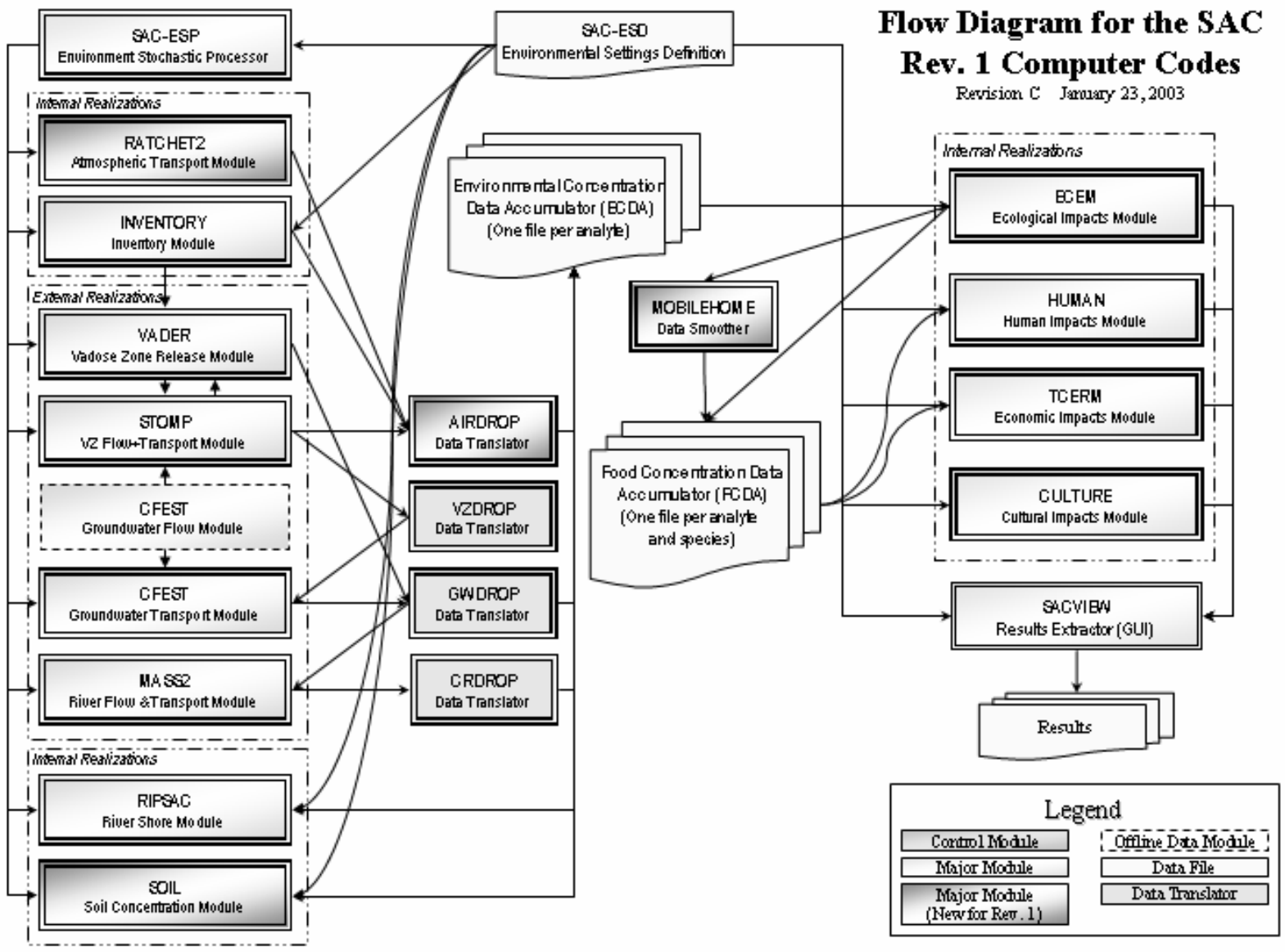

Figure 2.2. Information Flow in SAC Rev. 1 Software Design

(a) Groundwater/Vadose Zone Integration Project: Preliminary System Assessment Capability Concepts for Architecture, Platform and Data Management. (http://www.hanford.gov/cp/gpp/modeling/sacarchive/930rep.pdf) 
As can be seen in Figure 2.2, the SAC Rev. 1 Systems Code consists of a number of components that can be executed separately. A number of pieces of information, such as the site identification, coordinates, release model, hydrogeologic column (template), remediation action, infiltration class, and the start time and stop time of a simulated problem, are needed for the system components. The environmental settings definition (ESD) keyword file was designed to contain this common information. Generally, if information is needed by one or more modules of the suite of codes, it is entered in the ESD keyword file. A number of the ESD keywords are generated from general information on the waste site, its operational/ disposal history, and its environmental settings (past, current, and future). To facilitate the generation of these ESD keyword input files, a database termed the Geographic and Operational Site Parameters List (GOSPL) was assembled.

One of the challenges associated with performing an assessment is appropriately presenting how well the results predict what might actually occur. This is because the attributes of the site that effect transport of contaminants, the impact of contaminants on living systems, and the future conditions used in the assessment, as well as many other factors upon which the predictions depend, are not completely understood. SAC was developed to allow the performance of a probabilistic risk assessment so an indication of the effect of parameter uncertainty on results could be examined. In general, other sources of uncertainty, such as conceptual model uncertainty, will not be handled within the calculations but will be discussed in the interpretation of the results of this analysis.

For the 2004 Composite Analysis, SAC has been modified to enable the import of results from detailed assessments of individual waste sites by other Hanford Site programs/projects. Such results come from selected tank waste analyses (e.g., the Integrated Disposal Facility [IDF] Performance Assessment [Mann 2003]). Information on 1) release to vadose zone or 2) release to water table will be imported into the SAC deterministic analysis. The 2004 Composite Analysis will treat best estimate simulations by other Hanford Site programs as "median" simulations and incorporate them into an overall "median-input" deterministic simulation. For most waste sites simulated by others, the SAC modules will be adjusted to achieve comparable results.

To perform a stochastic analysis, best-estimate data (geologic profile, hydraulic properties, geochemical properties, recharge sequence, etc.) used by other Hanford Site programs to perform assessments will be interpreted as "median" values for distributions where the data range is defined by the Hanford-wide data set previously compiled for SAC. A simplified model (such as, release and one-dimensional vadose zone or release and two-dimensional vadose zone) will be calibrated to reproduce key aspects of the median simulation provided by the detailed assessment. This simplified but calibrated model will be used to generate the stochastic realizations. Where available, comparison will be made between the range of SAC stochastic responses and the range of deterministic sensitivity cases provided by the other Hanford Site program.

Significant differences may exist between the SAC representation of uncertainty and the representation of sensitivity created by other assessments. This is especially true when the site-specific assessment is using sensitivity analyses to explore alternate conceptual models of waste form release (for example, tank residuals modeled with a solubility model, diffusion model, advection-desorption model, linear release-time-model) or barrier performance (for example, alternate surface barriers and engineered containment systems surrounding a glass waste form). 


\subsection{Geographic and Operational Site Parameter List Definitions}

Of the more than 2,730 waste sites at Hanford and several storage sites, a subset of 1,046 sites was selected for inclusion in the 2004 Composite Analysis (Kincaid et al. 2004). A number of pieces of information are needed for the assessment, such as the site location, the release model, the hydrostratigraphic column (template), and the remedial action and infiltration assumptions. If this type of information is needed by one or more module of the suite of codes used by SAC, for a particular site, then the data are assembled for entry in the ESD keyword file. Of the 1,046 sites to be included in the 2004 Composite Analysis, 24 sites are primarily just place holders used to account for offsite transfers and nuclear material that are not directly simulated in any of the SAC codes. Thus, data have been assembled to enable the simulation of each of the 1,022 remaining sites, individually, using their site-specific parameters, and environmental settings. A master spreadsheet termed the Geographic and Operational Site Parameters List (or GOSPL) was developed for the initial assessments conducted using the SAC to define the site-specific location and facility design parameters as well as the key model assumptions for each assessment. GOSPL has continued to evolve as the site information and assessment basis has changed. It can generally be subdivided into three main sections: Site-Specific Parameters, ModelSpecific Instructions, and Remediation/Infiltration Assumptions. Brief descriptions of each key data field, including the source(s) of data are provided below. Note that other subordinate data fields that are not directly used by the current SAC modules are not described here. This version of GOSPL (containing the 1,022 sites to be individually simulated for the 2004 Composite Analysis) is provided in the appendix.

\subsection{Site-Specific Parameters}

Key site-specific geographic parameters used in the SAC include such input as the site identifiers (e.g., Site Code), general site design and operational history information, site geographic information (e.g., location), and facility dimensions. Much of this information is taken from WIDS. Please refer to the WIDS home page on the Hanford Intranet at http://apweb02.rl.gov/rapidweb/phmc/cp/wids/index.cfm?PageNum=1, and in particular the WIDS Data Field Definitions and Criteria http://apweb02.rl.gov/rapidweb/phmc/cp/wids/docs/5/docs/datacrit1.pdf.

\subsubsection{Site Identifiers}

There are three fields used to identify each specific site to be represented in the composite analysis: the WIDS Site Identification Number, the Site Code, and the Site Names.

\subsubsection{WIDS Site Identification Number (SiteId) - Site Table}

The WIDS SiteId (e.g., 575) provides a numeric identification number to uniquely identify each site record within WIDS. The primary data source for this information is the WIDS database, either directly or indirectly via the Hanford Site Waste Management Units Report (DOE 2003) or the QMAP geospatial map portal (http://www7.rl.gov/cfroot/knowledgenet/qmap/index.cfm). Future sites or facilities not contained in the WIDS database were assigned a SiteId equal to or greater than 9,900. 


\subsubsection{WIDS Site Code (SiteCode) - Site Table}

The SiteCode (e.g., 216-Z-9) is a unique alphanumeric identification tag (code) assigned to a site when it is entered into WIDS. The codes have been assigned in accordance with the facility naming conventions in use at the time the site was entered into the database or as modified during database reengineering. The site codes generally consist of a prefix indicating the designed area in which the site is located and its facility type (such as 100-D-, 216-B-, 618-), followed by a sequential number.

The primary data source for the SiteCode is the WIDS database. Planned or proposed future waste sites or facilities not contained in the WIDS database were assigned their own unique identifier by SAC project staff.

\subsubsection{WIDS Site Names (SiteNames) - Site Table}

The SiteNames field (e.g., 216-Z-9, 216-Z-9 Cavern, 234-5 Recuplex Cavern, 216-Z-10, 216-Z-9 Crib, 216-Z-9 Covered Trench) provides the common or working names by which the site is known, including all aliases for a site. The primary data source for this information is from WIDS and was obtained either directly from the WIDS database, or indirectly via the Hanford Site Waste Management Units Report (DOE 2003) or the QMAP geospatial map portal. The purpose of this field is to provide a cross reference to previously used site codes and names used in reference documents.

\subsubsection{General Site Design and Operational History Information}

General information on the design and operational history of the site is captured via four fields: site type, waste type, and start and end dates.

\subsubsection{Site Type (SiteType) - Site Table}

The SiteType (e.g., Trench) describes the structural design of the site. Generally, the site types are defined by the general function of the site (e.g., ground disposal) and its design (e.g., trench). The primary data source for this information is WIDS, and was obtained either directly from the WIDS database, or indirectly via the Hanford Site Waste Management Units Report (DOE 2003) or the QMAP geospatial map portal. The purpose of this field is to help describe the manner in which the sites were used to store or dispose of waste.

\subsubsection{Waste/Material Type (Type) - Waste Table}

The waste/material type describes the type of waste at the site in terms of its source, its appearance, its use before becoming a waste, or other general category (e.g., steam condensate, process effluent, bismuth phosphate metal waste). The primary source of this data is WIDS. If the information was missing from WIDS, then it may be that the type of waste was unknown or the information has not been entered. The purpose of this information is to allow grouping of sites into similar waste chemistry groups to aid selection and assignment of linear sorption coefficients. 


\subsubsection{Operational Start Date (StartDate) - Site Table}

The start date is the year the site started receiving waste. The primary source of this data is WIDS. If the information was missing from WIDS, then a start date was estimated from other nearby sites receiving similar waste types or servicing the same major process facilities.

\subsubsection{Operational End Date (EndDate) - Site Table}

The end date is the year the site stopped receiving waste. The primary source of this data is WIDS. If the information was missing from WIDS, then an end date was estimated from other nearby sites receiving similar waste types or servicing the same major process facilities.

\subsubsection{Geographic Information}

The basic geographic information captured for each site includes the site location and the type of feature used to represent the site within the Hanford Geographic Information System (HGIS) and Hanford Site Atlas (BHI 1998).

\subsubsection{Site Location (Center X Coordinate, Center Y Coordinate) - GisSite Table}

The $\mathrm{X}$ and $\mathrm{Y}$ coordinates for the site location are defined in terms of the Washington State Plane Easting and Northing coordinates (respectively), Southern Section, North American Datum 1983, in meters. The coordinate information represents the centroid of the site for sites mapped as a polygon. For sites mapped as a point (e.g., injection/reverse well), it represents the site itself. The primary data source for this information is WIDS, either directly from the WIDS database, or indirectly via the Hanford Site Waste Management Units Report (DOE 2003) or the QMAP geospatial map portal. However, coordinates are not recorded in WIDS for sites that are mapped as a line (e.g., sewers). So, for sites mapped as a line, and for sites where coordinate information is not available in WIDS, the centroid coordinates were estimated from HGIS documentation (i.e., the Hanford Site Atlas [BHI 1998]).

More detailed coordinate information was provided for large high volume liquid waste sites (e.g., ponds, ditches, cribs, and trenches) that might spatially overlap a number of different groundwater nodes. Rather than representing the centroid of the site, this information provides a number of key X,Y coordinate points that represent the perimeter of the site. Two fields are provided for this input, the number of coordinate points used to define the perimeter of the site, and the actual string of $\mathrm{X}, \mathrm{Y}$ coordinates.

Number of X, Y Coordinate Points. This field provides the number of distinct X, Y coordinate points included in the $\mathrm{X}, \mathrm{Y}$ coordinate string defined below.

X, Y Coordinate String. This field provides a string of paired X, Y coordinates used to define the perimeter of the site. The primary source of this information is estimates of selected key points used to represent the gross perimeter of the site as derived from the QMAP geospatial map portal (http://www7.rl.gov/cfroot/knowledgenet/qmap/index.cfm) or from HGIS documentation (i.e., the Hanford Site Atlas [BHI 1998]). 


\subsubsection{GIS Feature Type (GISFeatureType) - GisSite Table}

The Geographic Information System (GIS) feature type describes the spatial representation of the site features in the HGIS. This includes sites mapped as a polygon, point, or line.

\subsubsection{Facility Dimensions}

Facility dimensions are captured via five fields generally taken from the WIDS database. These data fields include: Site Length, Site Width, Site Depth (or Height), Site Diameter, and Site Area. In general, dimensions are provided in length and width fields or in the diameter field, but not both.

\subsubsection{Site Length (LengthMtrs) - Dimensions Table}

The site length is the longest dimension of a rectangular or nearly rectangular site. The primary source of this data is the WIDS database. If the data were not directly available from WIDS, then the site length was estimated from the QMAP geospatial map portal or HGIS documentation (i.e., the Hanford Site Atlas [BHI 1998]). If the value is blank, then it may be that the site length is unknown, or the information has not been entered (i.e., was not readily available for entry in the WIDS database).

\subsubsection{Site Width (WidthMtrs) - Dimensions Table}

The site width is the shortest dimension of a rectangular or nearly rectangular site. The primary source of this data is the WIDS database. If the data were not directly available from WIDS, then the site width was estimated from the QMAP geospatial map portal or HGIS documentation (i.e., the Hanford Site Atlas [BHI 1998]). If the value is blank, then it may be that the site width is unknown, or the information has not been entered (i.e., was not readily available for entry in the WIDS database).

\subsubsection{Site Depth/Height (DepthHeightMtrs) - Dimensions Table}

The site depth/height is the maximum depth of the site (in meters) below the ground surface or the maximum height of the unit above the ground surface. This includes the overburden depth. The primary source of this data is the WIDS database. If the value is blank, then it may be that the depth/height is unknown, or the information has not been entered (i.e., was not readily available for entry in the WIDS database).

\subsubsection{Site Diameter (DiameterMtrs) - Dimensions Table}

The site diameter is the distance (in meters) through the center of a circular or cylindrical (or nearly circular or cylindrical) site. The primary source of this data is the WIDS database. If the field is blank then it may be that the site diameter is unknown, there is no diameter (e.g., the site is rectangular), or the information has not been entered.

\subsubsection{Site Area (AreaSqMtrs) - Dimensions Table}

The site area is the surface extent of the site, measured in square meters. The primary source of this data is the WIDS database. If the data were not directly available from WIDS, then the site area was 
calculated from other site dimensions (i.e., site width and site length, or site diameter). If site dimension information was unavailable, then the area was estimated from the QMAP geospatial map portal or HGIS documentation (i.e., the Hanford Site Atlas [BHI 1998]). If data could not be found with which to estimate the site area, then the site was assigned a default value. Table 3.1 lists the default site area values used for different site types.

Table 3.1. Default Site Areas

\begin{tabular}{||l|c||}
\hline \multicolumn{1}{|c|}{ Site Type } & Default Area $\left(\mathrm{m}^{2}\right)$ \\
\hline \hline Unplanned Release, French Drain & 0.999 \\
\hline Storage Tank, Trench & 9.99 \\
\hline Radioactive Process Sewer, Crib & 99.9 \\
\hline Burial Ground & 999 \\
\hline
\end{tabular}

The site area is used to represent the footprint of the release area (e.g., the bottom area of a crib). However, a comparison of facility dimension information in WIDS with that by Maxfield (1979) suggests that the site area as recorded in WIDS is quite a bit bigger than the actual bottom area of the waste sites. It is believed that the site area represents the maximum surface extent of the facility, or perhaps even the fenced boundaries of the radiation zone surrounding the site. Thus, site area, as recorded in WIDS, may over estimate the actual footprint of the release area.

\subsection{Model-Specific Instructions}

This portion of GOSPL provides key model instructions for various components of the SAC system. This includes information regarding the release models and the vadose zone hydrogeologic templates.

\subsubsection{Selected for Simulation in the 2004 Composite Analysis}

This field identifies those sites that have been selected for simulation in the 2004 Composite Analysis. This field designates those sites selected for the 2004 Composite Analysis with a " 1 ," while those that will not be simulated are designated with a "0" or left blank.

\subsubsection{Release Model Designation}

The Release Models field is used to identify the type of release model that will be used in the SAC simulations. The designation for each site is based in part on the site type (see Section 3.1.2.1), the physical state of the waste (as taken from the PhysicalState field in the Waste Table of WIDS), and the material type (see Section 3.1.2.2). Table 3.2 lists the release model designations generally assigned by site type. Note that the release models assigned to each site are subjective in nature, based on best professional judgment, and may account for a combination of physiochemical processes (i.e., multiple release models). 
Table 3.2. Summary of Release Model Assignments to Waste Source Types (after Riley and LoPresti 2004)

\begin{tabular}{|c|c|c|}
\hline Release Model & Site (waste source) Type & \multirow[b]{2}{*}{ Exceptions } \\
\hline Atmosphere & Stacks & \\
\hline Liquid & $\begin{array}{l}\text { Single-shell tanks, }{ }^{(\mathrm{a})} \text { unplanned releases, }{ }^{(\mathrm{b})} \text { trenches, } \\
\text { cribs, drain/tile fields, radioactive process sewers, } \\
\text { French drains, retention basins, ponds, ditches, sumps, } \\
\text { injection/reverse wells, storage tanks, diversion boxes, } \\
\text { catch tanks, valve pits, settling tanks, receiving vaults, } \\
\text { and neutralization tanks }\end{array}$ & $\begin{array}{l}\text { Receiving vault } 241-\mathrm{WR} \_ \text {Vault will } \\
\text { be modeled using the cement model. }\end{array}$ \\
\hline Soil-Debris & $\begin{array}{l}\text { Unplanned releases, }{ }^{(b)} \text { sand filters, burial grounds, } \\
\text { laboratories, storage, stacks, }{ }^{(c)} \text { landfills, surplus } \\
\text { production sites (i.e., the soil below and surrounding a } \\
\text { site), storage tunnels }\end{array}$ & $\begin{array}{l}\text { The GTF Landfill contains grouted } \\
\text { waste, so the cement model should } \\
\text { be applied. Site } 116-C-2 C \text { will be } \\
\text { modeled as a liquid release. }\end{array}$ \\
\hline Cement & $\begin{array}{l}\text { Process unit/plants, control structures, cemented waste } \\
\text { in burial grounds }\end{array}$ & \\
\hline Salt-cake & Single-shell tanks, ${ }^{(\mathrm{a})}$ double-shell tanks ${ }^{(\mathrm{d})}$ & \\
\hline Reactor Block $^{(\mathrm{e})}$ & Decommissioned surplus production reactor cores & \\
\hline Glass $^{(f)}$ & Vitrified ILAW waste from single-shell tanks & \\
\hline River & Process sewer, outfall & \\
\hline $\begin{array}{l}\text { (a) Releases fro } \\
\text { (cement) mo } \\
\text { from dissolu } \\
\text { (b) Modeled as } \\
\text { (c) Modeled as } \\
\text { (d) Double-shel } \\
\text { solids model } \\
\text { (e) B reactor rel } \\
\text { remaining in } \\
\text { using the rea } \\
\text { (f) An empirica } \\
\text { generate stoc } \\
\text { GTF = Grou } \\
\text { ILAW = Imm } \\
\text { STORM = Subs } \\
\text { VADER = Vadc }\end{array}$ & $\begin{array}{l}\text { single-shell tanks will be modeled using a combination of } \\
\text { els. Releases include past tank leaks, liquid released during } \\
\text { on of residual solids following waste retrieval completion. } \\
\text { itial liquid release, release from surface contaminated soil } \\
\text { itial atmospheric release, then as soil-debris following its c } \\
\text { anks are assumed not to leak prior to and during retrieval. } \\
\text { d using salt-cake and/or diffusion (cement) model. } \\
\text { se occurs entirely in the } 100 \text { Area. Following a specified } \\
\text { entories for all other reactors are moved to a } 200 \text { Area buri } \\
\text { or block model. } \\
\text { nodel that approximates the results from the ILAW STOR } \\
\text { astic results through variation of recharge rate. } \\
\text { Treatment Facility. } \\
\text { oilized low-activity waste. } \\
\text { face Transport Over Reactive Multiphases. } \\
\text { e Zone Environmental Release. }\end{array}$ & $\begin{array}{l}\text { iquid, salt-cake, and/or diffusion } \\
\text { etrieval and contaminant release } \\
\text { a combination of both. } \\
\text { erational period. } \\
\text { Release of contaminants from residual } \\
\text { ariod of time ( } 75 \text { years). The } \\
\text { ground where release continues } \\
\text { I model, allowing SAC (VADER) to }\end{array}$ \\
\hline
\end{tabular}

\subsubsection{Vadose Zone Model Hydrostratigraphy}

Each site contained in GOSPL was assigned to a general vadose zone hydrostratigraphic profile based on its location within one of 26 geographic areas (representing 17 general geographic areas and 9 sitespecific locations), its site type (surface, near surface, tank, or injection well), and its waste chemistry designation. Each hydrostratigraphic profile (template) identifies the hydraulic and geochemical parameters necessary for STOMP to simulate the flow and transport through the vadose zone. As many as five variations of a single hydrostratigraphic template were incorporated to more accurately represent the depth of waste releases and the thickness of the vadose zone beneath the point of release. Additional 
variations of the hydrostratigraphic templates were necessary to accommodate variations in $\mathrm{K}_{\mathrm{d}}$ values associated with different waste chemistry designations. Thus, a series of 63 base templates were ultimately identified using a unique alphanumeric code consisting of a three-digit number that reflects the waste site type, a letter designating the geographic area, and a number designating the waste chemistry group for assigning $K_{d}$ values. Nine site-specific hydrostratigraphic templates were created by adding additional alphanumeric characters to the geographic area designation. These codes are explained below. A more complete discussion regarding the development of the vadose zone templates is provided by Last et al. (2004).

\subsubsection{VZ (Vadose Zone) Template Site Type (reflecting the depth of waste injection)}

The VZ Template Site Type Code (e.g., 216) generally consists of a three-digit number, with the first digit indicating the operational area in which the facility is located, and the second and third digits signifying the relative depth of waste release based on its facility type (such as 100-, 241-, 616-). This code is primarily derived from the WIDS SiteCode (see Section 3.1.1.2), the WIDS SiteType (see Section 3.1.2.1), the WIDS DepthHeightMtrs (see Section 3.1.4.3), and the WIDS Site Description (SiteDesc), which are used to classify the sites into six main categories reflecting the relative depth of waste release as defined in Table 3.3. This code identifies variants to the geographic area hydrostratigraphic columns to account for the thickness of the soil column beneath different waste release depths.

Table 3.3. Site Type Codes Used in the Hydrostratigraphic Templates

\begin{tabular}{|c|c|c|}
\hline $\begin{array}{l}\text { Site Type } \\
\text { Code }^{(a)}\end{array}$ & $\begin{array}{l}\text { Relative Depth of } \\
\text { Waste Release }\end{array}$ & Representative WIDS SiteTypes \\
\hline $\begin{array}{l}100,200,300, \\
400\end{array}$ & $\begin{array}{l}\text { Ground Surface (generally } \\
\text { less that } 3 \text { m deep). }\end{array}$ & $\begin{array}{l}\text { Surface and/or near surface facilities (e.g., process sewers, } \\
\text { reactor buildings, laboratory buildings, storage, stacks, ponds, } \\
\text { ditches, valve pits, process unit/plants, unplanned releases except } \\
\text { tank leaks). }\end{array}$ \\
\hline $\begin{array}{l}116,216,316, \\
616\end{array}$ & $\begin{array}{l}\text { Shallow Subsurface } \\
\text { (generally } 3-7 \text { m below } \\
\text { ground surface) }\end{array}$ & $\begin{array}{l}\text { Shallow liquid and/or dry waste disposal facilities (e.g., cribs, } \\
\text { burial grounds, retention basins, trenches, French drains, storage } \\
\text { tunnels, drain/tile fields, pipelines, sewers). }\end{array}$ \\
\hline 241 & $\begin{array}{l}\text { Intermediate Subsurface } \\
\text { (generally } 9 \text { to } 17 \mathrm{~m} \text { below } \\
\text { ground surface) }\end{array}$ & $\begin{array}{l}\text { High level waste tanks, settling tanks, diversion boxes, catch } \\
\text { tanks, tank leak unplanned releases. }\end{array}$ \\
\hline 166, 266 & $\begin{array}{l}\text { Deep Subsurface (generally } \\
\text { greater than } 18 \mathrm{~m} \text { below } \\
\text { ground surface) }\end{array}$ & Deep injection sites (e.g., reverse wells) \\
\hline 276 & $\begin{array}{l}\text { Very Deep Subsurface } \\
\text { (generally near or into the } \\
\text { water table) }\end{array}$ & Very deep injection sites (e.g., very deep reverse wells) \\
\hline River $^{(b)}$ & River Level & River outfalls and associated pipelines \\
\hline \multicolumn{3}{|c|}{$\begin{array}{l}\text { (a) First digit represents the area: } 1=100 \text { Area, } 2=200 \text { Area, } 3=300 \text { Area, } 4=400 \text { Area, } 6=600 \text { Area. } \\
\text { Second and third digits indicate the general facility type and relative release depth. } \\
\text { (b) River outfall discharged waste directly to the river, thus there is no vadose zone flow and transport } \\
\text { component for these sites. } \\
\text { WIDS = Waste Information Data System. }\end{array}$} \\
\hline
\end{tabular}




\subsubsection{Geographic Area}

Sixteen geographic areas were identified that could each be represented by a single generalized hydrostratigraphic column (Figure 3.1). Each of the six 100 Areas were designated as separate geographic areas because each area is geographically distinct and have distinct hydrogeologic characteristics. The 200 Areas were divided into six aggregate areas based on differences in hydrogeologic characteristics. The 200 West and 200 East Areas were each divided into two geographic areas. Additional geographic areas were designated for the 200 North Area, Gable Mountain Pond area, and the B-Pond area. A single geographic area was designated to encompass waste sites in the 300 Area. Finally, three additional geographic areas were defined for isolated sites in the 400 and 600 Areas. Table 3.4 presents the letter designations and brief descriptions of each geographic area. Nine site-specific designations were created by adding additional alphanumeric characters to two of the geographic area designations (Table 3.5).

\subsubsection{Waste Chemistry Group (for assigning $\mathbf{K}_{\mathrm{d}}$ ranges)}

Six waste chemistry types were defined by Kincaid et al. (1998) for use in the first composite analysis published in 1998. These waste chemistry types describe chemically distinct waste streams that impact the sorption of contaminants. These same waste chemistry designations were adapted for use in the initial assessment conducted using SAC to assign $\mathrm{K}_{\mathrm{d}}$ values to the vadose zone base templates (Bryce et al. 2002). However, based on the results of a recent compilation of contaminant distribution coefficients $\left(\mathrm{K}_{\mathrm{d}}\right)$ for Hanford sediments (Cantrell et al. 2003a, 2003b), the six waste stream categories used in these assessments were reduced to four (Table 3.6). ${ }^{\text {(a) }}$ Refer to the vadose zone data package (Last et al. 2004) for additional information regarding the assignment of these waste chemistry designations.

\subsubsection{VZ Base Templates}

A total of 61 base templates were identified based on various combinations of the site types, geographic areas, and waste chemistry types. This field is calculated by combining the information from the VZ Template Site Type, Geographic Area, and Waste Chemistry data fields, unless the VZ Template Site Type is "River," in which case this field is calculated as "River." However, if the Site Type is blank or the site is not on the list of sites for the composite analysis (i.e., the On Composite Analysis List field is " 0 ”), then this field is left blank. The general Excel formula used to calculate this field is as follows:

$$
=\operatorname{IF}(A=1, \operatorname{IF}(B=" \text { River", "River", IF }(B=\text { "'","', } B \& C \& "-" \& D)), " ')
$$

where $\mathrm{A}=$ On CA List

$\mathrm{B}=$ Site Type

$\mathrm{C}=$ Geographic Area

D = Waste Chemistry Group.

(a) Cantrell KJ, RJ Serne, and GV Last. Waste Stream Descriptions, Impact Zones and Associated $K_{d}$ Estimates Including Rational for Selections (Revision May 16, 2003). 


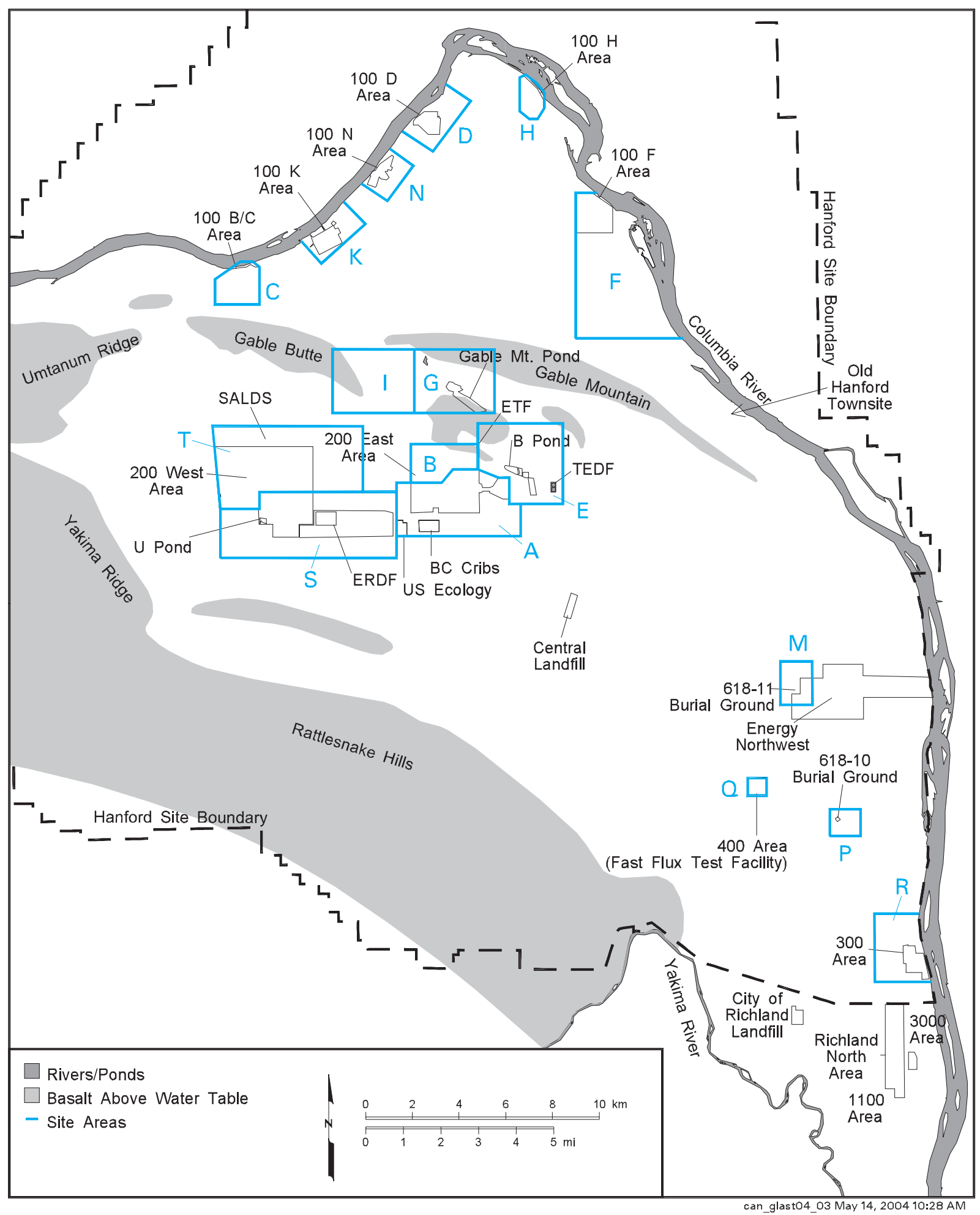

Figure 3.1. Geographic Areas Used to Define Different Hydrostratigraphic Profiles 
Table 3.4. Geographic Area Designations Used in the Hydrostratigraphic Template Codes

\begin{tabular}{||c|l||}
\hline \hline Designation & \multicolumn{1}{|c||}{ Geographic Area Description } \\
\hline \hline A & $\begin{array}{l}\text { Southern 200 East Area - encompassing the PUREX (A Plant), Hot Semi-Works (C-Plant), } \\
\text { associated facilities (including PUREX tunnels), US Ecology, and the A, AN, AP, AW, AX, AY, } \\
\text { AZ, C Tank Farms }\end{array}$ \\
\hline B & $\begin{array}{l}\text { Northwestern 200 East Area - encompassing the B-Plant Area, associated waste disposal } \\
\text { facilities, and the B, BX, BY Tank Farms }\end{array}$ \\
\hline C & 100-B/C Area \\
\hline D & $100-$-DR Area \\
\hline F & East of 200 East - B-Pond Area \\
\hline G & 100-F Area \\
\hline I & Gable Mountain Pond Area \\
\hline H & 100 North Area \\
\hline K & 100-KE/KW Area \\
\hline M & 600 Area near Energy Northwest and the 618-11 burial ground \\
\hline N & $100-$ N Area \\
\hline P & 600 Area southwest of the 400 Area near the 618-10 burial ground \\
\hline Q & 400 Area \\
\hline S & 300 Area (and a few isolated facilities in and near the 400 Area) \\
\hline T & $\begin{array}{l}\text { Southern 200 West Area - encompassing the REDOX (S-Plant), U-Plant, Z-Plant associated } \\
\text { facilities, ERDF, and the S, SX, SY, U Tank Farms }\end{array}$ \\
\hline $\begin{array}{l}\text { Northern 200 West Area - encompassing T Plant , associated facilities, and the T, TX, TY Tank } \\
\text { Farms }\end{array}$ \\
\hline $\begin{array}{l}\text { ERDF }=\text { Environmental Restoration Disposal Facility. } \\
\text { RERX }=\text { Plutonium-Uranium Extraction (Plant). }\end{array}$ \\
\hline
\end{tabular}

Table 3.5. Site-Specific Area Designations Used in the Hydrostratigraphic Template Codes

\begin{tabular}{||l|l||}
\hline \multicolumn{1}{|c||}{ Designation } & \multicolumn{1}{c||}{ Site-Specific Area Description } \\
\hline \hline A_BC_W & Southern 200 East Area - representing the western portion of the BC cribs area \\
\hline A_BC_E & Southern 200 East Area - representing the eastern portion of the BC cribs area \\
\hline A_BT_N & Southern 200 East Area - representing the northern portion of the BC trench area \\
\hline A_BT_S & Southern 200 East Area - representing the southern portion of the BC trench area \\
\hline A_BT_W & Southern 200 East Area - representing the western portion of the BC trench area \\
\hline A_ILAW_C & Southern 200 East Area - representing the central portion of the ILAW/IDF site \\
\hline S_U_N & Southern 200 West Area - representing the northern portion of the 216-U-1\&2 crib area \\
\hline S_U_S & Southern 200 West Area - representing the southern portion of the 216-U-1\&2 crib area \\
\hline S_Z9 & Southern 200 West Area - representing the 216-Z-9 trench area \\
\hline $\begin{array}{l}\text { IDF } \\
\text { ILAW }=\text { Integrated Disposal Facility. }\end{array}$ \\
\hline
\end{tabular}


Table 3.6. $\quad$ Waste Chemistry Groups Used in the Base Template Codes

\begin{tabular}{||c|l||}
\hline $\begin{array}{c}\text { Waste Chemistry } \\
\text { Designation }\end{array}$ & \multicolumn{1}{|c|}{ Waste Stream Description } \\
\hline \hline 1 & Very Acidic \\
\hline 2 & High Salt/Very Basic \\
\hline 3 & Chelates/High Salt \\
\hline 4 & Low Salt/Near Neutral \\
\hline
\end{tabular}

Table 3.7 provides a description of the general hydrostratigraphic templates established for each geographic area. Table 3.8 describes the site-specific templates set up for a number of key facilities within two of these general geographic areas.

Table 3.7. General Hydrostratigraphic Templates for Each Geographic Area

\begin{tabular}{|c|c|c|c|c|c|}
\hline \multirow{2}{*}{$\begin{array}{c}\text { VZ Base } \\
\text { Template } \\
\text { Designation }\end{array}$} & \multicolumn{2}{|c|}{ Geographic Area } & \multicolumn{2}{|c|}{ Waste Site Types } & \multirow{2}{*}{$\begin{array}{c}\text { Waste } \\
\text { Chemistry } \\
\text { Designation }^{(\mathrm{d})}\end{array}$} \\
\hline & Area & Designation $^{(a)}$ & Description & Designation $^{(b)}$ & \\
\hline 100C-4 & \multirow[t]{2}{*}{$100 \mathrm{~B} / \mathrm{C}$} & \multirow[t]{2}{*}{$\mathrm{C}$} & Surface Facilities & 100 & 4 \\
\hline 116C-4 & & & Near Surface Facilities & 116 & 4 \\
\hline 100D-4 & \multirow[t]{2}{*}{$100 \mathrm{D}$} & \multirow[t]{2}{*}{$\mathrm{D}$} & Surface Facilities & 100 & 4 \\
\hline 116D-4 & & & Near Surface Facilities & 116 & 4 \\
\hline $100 \mathrm{~F}-4$ & \multirow[t]{2}{*}{$100 \mathrm{~F}$} & \multirow[t]{2}{*}{$\mathrm{F}$} & Surface Facilities & 100 & 4 \\
\hline $116 \mathrm{~F}-4$ & & & Near Surface Facilities & 116 & 4 \\
\hline $100 \mathrm{H}-4$ & \multirow[t]{2}{*}{$100 \mathrm{H}$} & \multirow[t]{2}{*}{$\mathrm{H}$} & Surface Facilities & 100 & 4 \\
\hline $116 \mathrm{H}-4$ & & & Near Surface Facilities & 116 & 4 \\
\hline $100 \mathrm{~K}-4$ & \multirow[t]{3}{*}{$100 \mathrm{~K}$} & \multirow[t]{3}{*}{$\mathrm{K}$} & Surface Facilities & 100 & 4 \\
\hline $116 \mathrm{~K}-4$ & & & Near Surface Facilities & 116 & 4 \\
\hline $166 \mathrm{~K}-4$ & & & Reverse Wells & 166 & 4 \\
\hline $100 N-4$ & \multirow[t]{2}{*}{$100 \mathrm{~N}$} & \multirow[t]{2}{*}{$\mathrm{N}$} & Surface Facilities & 100 & 4 \\
\hline $116 N-4$ & & & Near Surface Facilities & 116 & 4 \\
\hline 200G-4 & Gable Mtn. Pond & $\mathrm{G}$ & Surface Facilities & 200 & 4 \\
\hline $200 \mathrm{I}-4$ & 200 North & $\mathrm{I}$ & Surface Facilities & 200 & 4 \\
\hline 200E-4 & $\begin{array}{l}\text { E } 200 \text { E } \\
\text { (B-Pond) }\end{array}$ & $\mathrm{E}$ & Surface Facilities & 200 & 4 \\
\hline 200B-2 & \multirow{7}{*}{$\begin{array}{l}\text { N } 200 \text { E } \\
\text { (B-Plant) }\end{array}$} & \multirow[t]{7}{*}{$\mathrm{B}$} & \multirow[t]{2}{*}{ Surface Facilities } & \multirow[t]{2}{*}{200} & 2 \\
\hline 200B-4 & & & & & 4 \\
\hline $216 B-3$ & & & \multirow[t]{2}{*}{ Near Surface Facilities } & \multirow[t]{2}{*}{216} & 3 \\
\hline 216B-4 & & & & & 4 \\
\hline 241B-2 & & & Tanks & 241 & 2 \\
\hline 266B-4 & & & \multirow[t]{2}{*}{ Reverse Wells } & 266 & 4 \\
\hline $267 \mathrm{~B}-2$ & & & & $267^{(\mathrm{c})}$ & 2 \\
\hline
\end{tabular}


Table 3.7. (contd)

\begin{tabular}{|c|c|c|c|c|c|}
\hline \multirow{2}{*}{$\begin{array}{l}\text { VZ Base } \\
\text { Template } \\
\text { Designation }\end{array}$} & \multicolumn{2}{|c|}{ Geographic Area } & \multicolumn{2}{|c|}{ Waste Site Types } & \multirow{2}{*}{$\begin{array}{c}\text { Waste } \\
\text { Chemistry } \\
\text { Designation }^{(\mathrm{d})}\end{array}$} \\
\hline & Area & Designation $^{(\mathrm{a})}$ & Description & Designation $^{(b)}$ & \\
\hline 200A-2 & \multirow{7}{*}{$\begin{array}{l}\text { S } 200 \text { E (PUREX, } \\
\text { BC Cribs) }\end{array}$} & \multirow[t]{7}{*}{ A } & \multirow[t]{2}{*}{ Surface Facilities } & \multirow[t]{2}{*}{200} & 2 \\
\hline $200 \mathrm{~A}-4$ & & & & & 4 \\
\hline $216 \mathrm{~A}-2$ & & & \multirow[t]{2}{*}{ Near Surface Facilities } & \multirow[t]{2}{*}{216} & 2 \\
\hline $216 \mathrm{~A}-4$ & & & & & 4 \\
\hline $241 \mathrm{~A}-2$ & & & \multirow[t]{2}{*}{ Tanks } & \multirow[t]{2}{*}{241} & 2 \\
\hline $241 \mathrm{~A}-3$ & & & & & 3 \\
\hline $266 \mathrm{~A}-4$ & & & Reverse Wells & 266 & 4 \\
\hline $200 \mathrm{~S}-2$ & \multirow{2}{*}{$\begin{array}{l}\text { S } 200 \text { W (REDOX, } \\
\text { U-Plant, Z-Plant) }\end{array}$} & \multirow[t]{2}{*}{$S$} & \multirow[t]{2}{*}{ Surface Facilities } & \multirow[t]{2}{*}{200} & 2 \\
\hline $200 S-4$ & & & & & 4 \\
\hline $216 S-1$ & \multirow{7}{*}{$\begin{array}{l}\text { S } 200 \text { W (REDOX, } \\
\text { U-Plant, Z-Plant) }\end{array}$} & \multirow[t]{7}{*}{$S$} & \multirow[t]{3}{*}{ Near Surface Facilities } & \multirow[t]{3}{*}{216} & 1 \\
\hline $216 S-2$ & & & & & 2 \\
\hline $216 S-4$ & & & & & 4 \\
\hline 241S-2 & & & \multirow[t]{3}{*}{ Tanks } & \multirow[t]{3}{*}{241} & 2 \\
\hline 241S-3 & & & & & 3 \\
\hline $241 S-4$ & & & & & 4 \\
\hline $266 \mathrm{~S}-4$ & & & Reverse Wells & 266 & 4 \\
\hline 200T-2 & \multirow[t]{8}{*}{ N 200 W (T-Plant) } & \multirow[t]{8}{*}{$\mathrm{T}$} & \multirow[t]{2}{*}{ Surface Facilities } & \multirow[t]{2}{*}{200} & 2 \\
\hline 200T-4 & & & & & 4 \\
\hline $216 \mathrm{~T}-2$ & & & \multirow[t]{3}{*}{ Near Surface Facilities } & \multirow[t]{3}{*}{216} & 2 \\
\hline 216T-3 & & & & & 3 \\
\hline 216T-4 & & & & & 4 \\
\hline 241T-2 & & & Tanks & 241 & 2 \\
\hline $266 \mathrm{~T}-2$ & & & \multirow[t]{2}{*}{ Reverse Wells } & \multirow[t]{2}{*}{266} & 2 \\
\hline 266T-4 & & & & & 4 \\
\hline 300R-4 & 300 Area (North & $\mathrm{R}$ & Surface Facilities & 300 & 4 \\
\hline 316R-4 & Richland & & Near Surface Facilities & 316 & 4 \\
\hline 400Q-4 & 400 & $\mathrm{Q}$ & Surface Facilities & 400 & 4 \\
\hline $616 \mathrm{M}-4$ & 600 & $\mathrm{M}$ & Near Surface Facilities & 616 & 4 \\
\hline 616P-4 & 600 & $\mathrm{P}$ & Near Surface Facilities & 616 & 4 \\
\hline River & - & - & River & - & - \\
\hline $\begin{array}{l}\text { (a) Assigne } \\
\text { (b) Assigne } \\
100,200 \\
\text { surface } \\
\text { (c) Two des } \\
\text { The "67 } \\
\text { (d) Assigne } \\
\text { PUREX = } \\
\text { REDOX = }\end{array}$ & $\begin{array}{l}\text { letter designation for } \\
\text { number designation } \mathrm{f} \\
\text {, 300, } 400,600 \text { Areas) } \\
\text { acilities, } 41=\text { tanks, } \\
\text { ignations are used for } \\
\text { designation distingui } \\
\text { number designation } \\
\text { Plutonium-Uranium Ex } \\
\text { Reduction Oxidation ( }\end{array}$ & $\begin{array}{l}\text { geographic area. } \\
\text { or waste site typ } \\
\text { last two numbe } \\
/ 67=\text { reverse we } \\
\text { everse wells tha } \\
\text { hes the very dee } \\
\text { or waste chemist } \\
\text { traction (Plant). } \\
\text { lant). }\end{array}$ & $\begin{array}{l}\text { first number designates } \\
\text { designate waste site typ } \\
\text { lss) } \\
\text { have very different depth } \\
\text { reverse wells from those } \\
\text { y type (see Table } 3.6 \text { ). }\end{array}$ & $\begin{array}{l}\text { titional Hanford } \\
0=\text { surface facili } \\
\text { ithin a single geo } \\
\text { a more intermedi }\end{array}$ & $\begin{array}{l}\text { te area (i.e., } \\
\text { es, } 16 \text { = near } \\
\text { aphic area. } \\
\text { e depth (66). }\end{array}$ \\
\hline
\end{tabular}


Table 3.8. $\quad$ Site-Specific Templates Established for a Few Key Facilities

\begin{tabular}{|c|c|c|c|c|c|}
\hline \multirow{2}{*}{$\begin{array}{l}\text { Template } \\
\text { Designation }\end{array}$} & \multicolumn{2}{|c|}{ Site-Specific Area } & \multicolumn{2}{|c|}{ Waste Site Types } & \multirow{2}{*}{$\begin{array}{c}\text { Waste } \\
\text { Chemistry } \\
\text { Designation } \\
\text { (d) }\end{array}$} \\
\hline & Area & Designation $^{(\mathrm{a})}$ & Description & Designation $^{(\mathrm{b})}$ & \\
\hline 216A_BC_W-3 & $\begin{array}{l}\text { S } 200 \text { E, BC Cribs, } \\
\text { Western Portion }\end{array}$ & A_BC_W & $\begin{array}{l}\text { Near Surface } \\
\text { Facilities }\end{array}$ & 216 & 3 \\
\hline 216A_BC_E-3 & $\begin{array}{l}\text { S } 200 \text { E, BC Cribs, } \\
\text { Eastern Portion }\end{array}$ & A_BC_E & $\begin{array}{l}\text { Near Surface } \\
\text { Facilities }\end{array}$ & 216 & 3 \\
\hline 216A_BT_N-3 & \multirow{2}{*}{$\begin{array}{l}\text { S } 200 \text { E, BC Trenches, } \\
\text { Northern Portion }\end{array}$} & \multirow[t]{2}{*}{ A_BT_N } & \multirow{2}{*}{$\begin{array}{l}\text { Near Surface } \\
\text { Facilities }\end{array}$} & \multirow[t]{2}{*}{216} & 3 \\
\hline 216A_BT_N-4 & & & & & 4 \\
\hline 216A_BT_S-3 & $\begin{array}{l}\text { S } 200 \text { E, BC Trenches, } \\
\text { Southern Portion }\end{array}$ & A_BT_S & $\begin{array}{l}\text { Near Surface } \\
\text { Facilities }\end{array}$ & 216 & 3 \\
\hline 216A_BT_W-3 & $\begin{array}{l}\text { S } 200 \text { E, BC Trenches, } \\
\text { Western Portion }\end{array}$ & A_BT_W & $\begin{array}{l}\text { Near Surface } \\
\text { Facilities }\end{array}$ & 216 & 3 \\
\hline 216A_ILAW_C-3 & $\begin{array}{l}\text { S } 200 \text { E, ILAW Site, } \\
\text { Central Portion }\end{array}$ & A_ILAW_C & $\begin{array}{l}\text { Near Surface } \\
\text { Facilities }\end{array}$ & 216 & 3 \\
\hline 216S_U_N-4 & $\begin{array}{l}\text { S } 200 \text { W, 216-U-1\&2 } \\
\text { Area, Northern Portion }\end{array}$ & S_U_N & $\begin{array}{l}\text { Near Surface } \\
\text { Facilities }\end{array}$ & 216 & 4 \\
\hline 216S_U_S-4 & $\begin{array}{l}\text { S } 200 \mathrm{~W}, 216-\mathrm{U}-1 \& 2 \\
\text { Area, Northern Portion }\end{array}$ & S_U_S & $\begin{array}{l}\text { Near Surface } \\
\text { Facilities }\end{array}$ & 216 & 4 \\
\hline 216S_Z9-1 & $\begin{array}{l}\text { S } 200 \text { W, 216-U-1\&2 } \\
\text { Area, Northern Portion }\end{array}$ & S_Z9 & $\begin{array}{l}\text { Near Surface } \\
\text { Facilities }\end{array}$ & 216 & 1 \\
\hline $\begin{array}{l}\text { (a) Assigned letter } \\
\text { (b) Assigned numb } \\
100,200,300 \text {, } \\
\text { surface faciliti } \\
\text { (c) Two designatic } \\
\text { The "67" desig } \\
\text { (d) Assigned numb } \\
\text { ILAW = Immobiliz }\end{array}$ & $\begin{array}{l}\text { designation for geographi } \\
\text { er designation for waste s } \\
\text { 100, } 600 \text { Areas); last two } \\
\text { s, } 41=\text { tanks, 66/67 = rev } \\
\text { hs are used for reverse we } \\
\text { lation distinguishes the ve } \\
\text { er designation for waste c } \\
\text { d low-activity waste. }\end{array}$ & $\begin{array}{l}\text { area. } \\
\text { type: first num } \\
\text { imbers designate } \\
\text { se wells) } \\
\text { s that have very } \\
\text { y deep reverse } \mathrm{w} \\
\text { emistry type (see }\end{array}$ & $\begin{array}{l}\text { ber designates tr } \\
\text { waste site type ( } \\
\text { lifferent depths } \\
\text { ells from those a } \\
\text { Table 3.6). }\end{array}$ & $\begin{array}{l}\text { tional Hanford } \$ \\
=\text { surface facilit } \\
\text { hin a single geo } \\
\text { more intermedia }\end{array}$ & $\begin{array}{l}\text { ite area (i.e., } \\
\text { es, } 16 \text { = near } \\
\text { raphic area. } \\
\text { e depth (66). }\end{array}$ \\
\hline
\end{tabular}

\subsubsection{Site Template}

The Site Template uniquely identifies the site for the set of geographic and operational parameters to be used for the vadose zone simulations. For the 2004 Composite Analysis, this field is identical to that of the WIDS Site Code (see Section 3.1.1.2). However, this field has been used to aggregate multiple sites to a single template.

\subsection{Remediation/Recharge Assumptions}

This portion of GOSPL provides key assumptions regarding the surface soil conditions and deep drainage (recharge) at each waste site. These soil conditions and recharge estimates were derived from a suite of available field data and computer simulation results and assembled into a suite of recharge classes that describe the probability distribution function for recharge at the site. Recharge classes are defined for 
a number of different time intervals: Pre-Hanford, Operations, Post-Remediation, and Post-Hanford. Each recharge class was identified with a unique code based on either the primary native soil and vegetation type or the type and size of the surface barrier. Refer to the vadose zone data package (Last et al. 2004) for details.

\subsubsection{Pre-Hanford Recharge Class}

This field defines the recharge class to be applied to the simulations for the time period prior to the establishment of the Hanford Site in 1943. The source of this information is the vadose zone data package (Last et al. 2004), which generally assumed a natural soil cover with undisturbed shrub-steppe plant community and based on the Hanford soil map produced by Hajek (1966). Table 3.9 lists the PreHanford Recharge Classes used for the 2004 Composite Analysis.

Table 3.9. $\quad$ Pre-Hanford Recharge Classes for the 2004 Composite Analysis

\begin{tabular}{||l|l|c|c|c|c||}
\hline \multicolumn{1}{||}{$\begin{array}{l}\text { Recharge } \\
\text { Class Code }\end{array}$} & \multicolumn{1}{|c|}{ Description } & $\begin{array}{c}\text { Best } \\
\text { Estimate } \\
\text { (mm/yr) }\end{array}$ & $\begin{array}{c}\text { Estimated } \\
\text { Standard } \\
\text { Deviation } \\
\text { (mm/yr) }\end{array}$ & $\begin{array}{c}\text { Minimum } \\
\text { (mm/yr) }\end{array}$ & $\begin{array}{c}\text { Maximum } \\
\text { (mm/yr) }\end{array}$ \\
\hline \hline Eb-s & $\begin{array}{l}\text { Ephrata stony loam (Eb) - with shrub-steppe (s) } \\
\text { plant community }\end{array}$ & 1.5 & 0.75 & 0.75 & 3.0 \\
\hline El-s & $\begin{array}{l}\text { Ephrata sandy loam (El) - with shrub-steppe (s) } \\
\text { plant community }\end{array}$ & 1.5 & 0.75 & 0.75 & 3.0 \\
\hline Ba-s & $\begin{array}{l}\text { Burbank loamy sand (Ba) - with shrub-steppe (s) } \\
\text { plant community }\end{array}$ & 3.0 & 1.5 & 1.5 & 6.0 \\
\hline Rpe-s & $\begin{array}{l}\text { Rupert sand (Rp) in 200 East (e) - with shrub- } \\
\text { steppe (s) plant community }\end{array}$ & 0.9 & 0.45 & 0.45 & 1.8 \\
\hline Rp-s & $\begin{array}{l}\text { Rupert sand (Rp) outside 200 East - with shrub- } \\
\text { steppe (s) plant community }\end{array}$ & 4.0 & 2.0 & 2.0 & 8.0 \\
\hline River & $\begin{array}{l}\text { Assumes discharge directly to the river, no } \\
\text { release or vadose zone modeling is required, so } \\
\text { recharge rates are not applicable. }\end{array}$ & NA & NA & NA & NA \\
\hline NA = Not applicable. & & & & \\
\hline
\end{tabular}

\subsubsection{Operational Recharge Class}

This field defines the recharge classes to be used for simulations for the time period during and after site operations, prior to any site remediation. Once again, the source of this information comes directly from the vadose zone data package (Last et al. 2004). This generally assumes that the site is covered by native soils or backfilled soils with or without vegetation; asphalt, buildings, concrete, or gravel covers. Table 3.10 lists the Operational Recharge Classes used for the 2004 Composite Analysis. 
Table 3.10. Operational Recharge Classes for the 2004 Composite Analysis

\begin{tabular}{|c|c|c|c|c|c|}
\hline $\begin{array}{l}\text { Recharge } \\
\text { Class Code }\end{array}$ & Description & $\begin{array}{l}\text { Best } \\
\text { Estimate } \\
(\mathrm{mm} / \mathrm{yr})\end{array}$ & $\begin{array}{c}\text { Estimated } \\
\text { Standard } \\
\text { Deviation } \\
(\mathrm{mm} / \mathrm{yr})\end{array}$ & $\begin{array}{l}\text { Minimum } \\
(\mathrm{mm} / \mathrm{yr})\end{array}$ & $\begin{array}{l}\operatorname{Maximum} \\
(\mathrm{mm} / \mathrm{yr})^{(\mathrm{a})}\end{array}$ \\
\hline Eb-dn & $\begin{array}{l}\text { Ephrata stony loam }(E b) \text {, disturbed }(d) \text { - with no } \\
\text { (n) vegetation }\end{array}$ & 17 & 8.5 & 8.5 & 34 \\
\hline El-dn & $\begin{array}{l}\text { Ephrata sandy loam (El), disturbed (d) - with no } \\
\text { (n) vegetation }\end{array}$ & 17 & 8.5 & 8.5 & 34 \\
\hline Ba-dg & $\begin{array}{l}\text { Burbank loamy sand }(\mathrm{Ba}) \text {, disturbed }(\mathrm{d}) \text { - with } \\
\text { cheatgrass (g) plant community }\end{array}$ & 26 & 13.0 & 13.0 & 52 \\
\hline Ba-dn & $\begin{array}{l}\text { Burbank loamy sand }(\mathrm{Ba}) \text {, disturbed }(\mathrm{d}) \text { - with no } \\
\text { (n) vegetation }\end{array}$ & 53 & 26.5 & 26.5 & 101 \\
\hline Rpe-dn & $\begin{array}{l}\text { Rupert sand }(\mathrm{Rp}) \text { in } 200 \text { East, disturbed }(\mathrm{d}) \text { - with } \\
\text { no (n) vegetation }\end{array}$ & 44 & 22 & 22 & 88 \\
\hline Rp-dn & $\begin{array}{l}\text { Rupert sand (Rp) outside } 200 \text { East, disturbed (d) - } \\
\text { with no (n) vegetation }\end{array}$ & 44 & 22 & 22 & 88 \\
\hline G-dn & $\begin{array}{l}\text { Gravel surface (G), disturbed - with no (n) } \\
\text { vegetation }\end{array}$ & 89 & 44.5 & 44.5 & 101 \\
\hline $\mathrm{ABC}$ & $\begin{array}{l}\text { Soil Surface covered by Asphalt, Building, or } \\
\text { Concrete }\end{array}$ & 0.1 & 0.05 & 0.05 & 0.2 \\
\hline River & $\begin{array}{l}\text { Assumes discharge directly to the river, no release } \\
\text { or vadose zone modeling is required, so recharge } \\
\text { rates are not applicable. }\end{array}$ & NA & NA & NA & NA \\
\hline
\end{tabular}

\subsubsection{Interim Remedial Actions (IRA-1 and IRA-2)}

Interim remedial actions (IRA) have been identified or proposed for some sites. Currently, GOSPL is configured to handle two different interim remedial action events (IRA-1 and IRA-2). For these particular sites, three additional fields have been defined (Year Interim Remedial Action Complete, Interim Remedial Action Type, and Interim Barrier/Soil Cover Type) for each remedial action event defined. The primary source of this information was from Maxfield (1979) or the WIDS database (via the Hanford Site Waste Management Units Report [DOE 2003]). An example for the BC cribs and trenches is shown in Table 3.11, with the fields in that table as defined below.

\subsubsection{Year Interim Remedial Action Complete (year IRA-1 complete; year IRA-2 complete)}

This field defines the year that the interim remedial action was completed. 
Table 3.11. Example of Interim Remedial Actions Defined for the 2004 Composite Analysis

\begin{tabular}{||l|c|c|c|c|c|c||}
\hline \multirow{2}{*}{$\begin{array}{c}\text { WIDS Site } \\
\text { Code }\end{array}$} & $\begin{array}{c}\text { Year } \\
\text { Complete }\end{array}$ & Type & $\begin{array}{c}\text { Barrier/Soil } \\
\text { Type }\end{array}$ & $\begin{array}{c}\text { Year } \\
\text { Complete }\end{array}$ & IRA-2 \\
\cline { 2 - 7 } Type & $\begin{array}{c}\text { Barrier/Soil } \\
\text { Type }\end{array}$ \\
\hline \hline $216-B-14$ & 1981 & ABAR & Rp-ds & & ABAR & Rpe-ds \\
\hline $216-B-20$ & 1969 & ABAR & G-dn & 1982 & & \\
\hline $\begin{array}{l}\text { ABAR }= \\
\text { IRA Aggregate barrier. } \\
\text { WIDS }=\text { Interim remedial actions. }\end{array}$ \\
\hline \hline
\end{tabular}

\subsubsection{Interim Remedial Action Type (IRA-1 type, IRA-2 type)}

This field defines the type of interim remedial action that was taken at the site. For the 2004 Composite Analysis, this includes: (1) remove, treat, and dispose (RTD) or (2) surface stabilization (e.g., aggregate barrier [ABAR], isolated barrier [IBAR]).

\subsubsection{Interim Barrier/Soil Type (recharge class) (IRA-1 barrier/soil type; IRA-2 barrier/soil type)}

This field, when populated, defines the recharge class to be applied to the site during the period after interim remediation and prior to any other interim remediation or final site remediation. For the 2004 Composite Analysis only three IRA recharge classes have been identified, G-dn (as described in Table 3.10) and Rp-ds and Rpe-ds (as described in Table 3.12).

\subsubsection{Remediation}

Some form of remediation (or no action) was identified for each site. A number of data fields were used to define the recharge classes to be used during the period following remediation and prior to the long-term post-remediation/closure design-life. The primary source of this information comes from the Hanford Disposition Baseline and Kincaid et al. (2004). These sources determined the schedule and type of remediation (e.g., engineered surface barriers) to be applied to each site for the 2004 Composite Analysis. The vadose zone data package (Last et al. 2004) describes the assumptions regarding the recharge rates to be used for barriers during the institutional control period, their design life, and after their design life. A key assumption of the 2004 Composite Analysis is that deep drainage beneath barrier side slopes and the surrounding terrain does not appreciably affect contaminant release from immediately below the barrier, nor transport in the vadose zone to the water table. This assumption is consistent with the previous composite analysis as well as recent and ongoing assessments.

\subsubsection{Year Remedial Action Complete}

This field defines the planned (or actual) year that remediation will be (or was) completed at the site. This assumes that all remedial action for that particular site is completed within a given year. For those sites slated for no further action, a value of "NA" was used, indicating that the recharge class would not change from its pre-remediation time period. 


\subsubsection{Remediation Type}

This field identifies the type of remedial action planned (or completed) for the site, including: no action; decontamination and decommissioning (D\&D); remove, treat, and dispose (RTD); isolated barriers (IBAR), or aggregate barriers (ABAR). This field identifies a number of different aggregate barriers defined by a unique alphanumeric code, with the same code assigned to all sites to be covered by the same aggregate barrier.

\subsubsection{Barrier Type}

This field identifies the type of barrier planned (or completed) for the site. If the remediation type is anything other than an IBAR or ABAR, then this field is blank. Otherwise this field contains either Resource Conservation and Recovery Act (RCRA) C or Hanford to designate the two types of surface barriers currently planned for Hanford waste sites.

\subsubsection{Barrier Infiltration Class}

This field assigns an infiltration (recharge) class to those sites that are to receive a surface barrier. If the remediation type (Section 3.3.6.2) is anything other than an IBAR or ABAR, then this field is blank. Otherwise this field is calculated from a lookup table of barrier infiltration classes based on the estimated barrier top-to-side slope ratio. It was developed to help address the possible effects of side slopes on barrier recharge rates. However, for the 2004 Composite Analysis it is assumed that deep drainage beneath the barrier side slopes and the surrounding terrain does not appreciably affect contaminant release and transport (Last et al. 2004). Thus far, for the baseline case of the 2004 Composite Analysis, the actual values in this field are of no consequence. These infiltration assignments that account for side slope influence may be used in a sensitivity case.

\subsubsection{Post Remediation Recharge Classes}

This field provides the recharge class to be used for the post-remediation time period (i.e., following site remediation and prior to any soil/barrier evolution/degradation). This field is calculated by combining the information from the Barrier Type and Barrier Infiltration Class, if the Barrier Type is not blank, or by modifying the information in the Pre-Operations Recharge Class to replace the suffix with “-ds" (to reflect disturbed shrub-steppe vegetation). If the VZ Template Site Type is "River," then this field is calculated as "River." The general Excel formula used to calculate this field is as follows:

$$
=\operatorname{IF}(A=" \text { ", IF (B =" River", "River", REPLACE(C, SEARCH("-", C,1),2, "-ds")), D\&"-"\&A) }
$$

where

$$
\begin{aligned}
& \text { A }=\text { Barrier Infiltration Class } \\
& \text { B }=\text { Vadose Zone Template Type } \\
& \text { C }=\text { Pre-Operations Infiltration Class } \\
& \text { D }=\text { Barrier Type. }
\end{aligned}
$$


Table 3.12 lists the post-remediation recharge classes for the composite analysis. Note that for this composite analysis all sizes of RCRA C and Hanford Barriers have the same estimated recharge rates (i.e., there are no side-slope effects). Refer to the vadose zone data package (Last et al. 2004) for further discussion.

Table 3.12. $\quad$ Post-Remediation Recharge Classes

\begin{tabular}{|c|c|c|c|c|c|}
\hline $\begin{array}{l}\text { Recharge } \\
\text { Class Code }\end{array}$ & Description & $\begin{array}{l}\text { Best } \\
\text { Estimate } \\
(\mathrm{mm} / \mathrm{yr})\end{array}$ & $\begin{array}{c}\text { Estimated } \\
\text { Standard } \\
\text { Deviation } \\
(\mathrm{mm} / \mathrm{yr})\end{array}$ & $\begin{array}{l}\text { Minimum } \\
(\mathrm{mm} / \mathrm{yr})\end{array}$ & $\underset{(\mathrm{mm} / \mathrm{yr})}{\operatorname{Maximum}}$ \\
\hline $\begin{array}{l}\text { RCRA } \\
\text { C-Ixx }\end{array}$ & Modified RCRA C - barrier top during design life & 0.1 & 0.05 & 0.05 & 0.20 \\
\hline $\begin{array}{l}\text { Hanford- } \\
\text { Ixx }\end{array}$ & Hanford Barrier - barrier top during design life & 0.1 & 0.05 & 0.05 & 0.20 \\
\hline Ba-ds & $\begin{array}{l}\text { Burbank loamy sand }(\mathrm{Ba}) \text {, disturbed }(\mathrm{d}) \text { - with } \\
\text { young shrub-steppe (s) plant community }\end{array}$ & 6.0 & 3.0 & 3.0 & 12 \\
\hline Eb-ds & $\begin{array}{l}\text { Ephrata stony loam }(\mathrm{Eb}) \text {, disturbed }(\mathrm{d}) \text { - with } \\
\text { young shrub-steppe (s) vegetation }\end{array}$ & 3.0 & 1.5 & 1.5 & 6.0 \\
\hline El-ds & $\begin{array}{l}\text { Ephrata sandy loam }(\mathrm{El}) \text {, disturbed }(\mathrm{d}) \text { - with } \\
\text { young shrub-steppe (s) vegetation }\end{array}$ & 3.0 & 1.5 & 1.5 & 6.0 \\
\hline Rp-ds & $\begin{array}{l}\text { Rupert sand (Rp) outside } 200 \text { East, disturbed (d) - } \\
\text { with young shrub-steppe (s) plant community }\end{array}$ & 8.0 & 4.0 & 4.0 & 16.0 \\
\hline Rpe-ds & $\begin{array}{l}\text { Rupert sand (Rp) in } 200 \text { East, disturbed (d) - with } \\
\text { young shrub-steppe (s) plant community }\end{array}$ & 1.8 & 0.9 & 0.9 & 3.6 \\
\hline River & $\begin{array}{l}\text { Assumes discharge directly to the river, no release } \\
\text { or vadose zone modeling is required, so recharge } \\
\text { rates are not applicable. }\end{array}$ & NA & NA & NA & NA \\
\hline
\end{tabular}

\subsubsection{Post-Remediation/Barrier Design Life}

This field defines the design life of the post-remediation period (i.e., that period after remediation is complete and prior to any significant degradation of the surface soils (e.g., barrier) or succession of plant communities). Table 3.13 lists the Post-Remediation/Barrier Design Life. 
Table 3.13. Post-Remediation/Barrier Design Life

\begin{tabular}{|l|c||}
\hline \multicolumn{1}{|c||}{ Post-Remediation Soil Conditions (recharge classes) } & Design Life (years) \\
\hline \hline $\begin{array}{l}\text { Native soil with young shrub-steppe plant community (Ba-ds, Eb-ds, El-ds, Rp-ds, } \\
\text { Rpe-ds) }\end{array}$ & 30 \\
\hline RCRA C surface barrier & 500 \\
\hline Hanford surface barrier & 1,000 \\
\hline River $\quad$ NA \\
\hline $\begin{array}{l}\text { NA } \quad \text { Not applicable. } \\
\text { RCRA }=\text { Resource Conservation and Recovery Act. }\end{array}$ \\
\hline
\end{tabular}

\subsubsection{Barrier End Date}

This field defines the date at which the post-remediation recharge period ends and the final long-term recharge period begins. This field is calculated by adding the Design Life to the Year Remedial Action Complete. However, if the Release Model Designation is "River," then this field is calculated as "NA," or if the Year Remedial Action Complete field is "NA," then this field is calculated as "2010." The general Excel formula used to calculate this field is as follows:

$$
=\operatorname{IF}\left(A=" \text { River", "NA", } \operatorname{IF}\left(B=" N A^{\prime}, 2010, B+C\right)\right)
$$

where $\quad \mathrm{A}=$ Release Model Designation

$\mathrm{B}=$ Year Remedial Action Complete

C = Post-remediation/Barrier Design Life.

\subsubsection{Final Long-Term Recharge Class}

This field defines the final long-term recharge class to be used for the final simulation period. This field is calculated as being equal to the Pre-Operational Infiltration Class.

\subsection{Conclusions and Recommendations}

A composite analysis is required by U.S. Department of Energy (DOE) Order 435.1 to ensure public safety through the management of active and planned low-level radioactive waste disposal facilities associated with the Hanford Site. Kincaid et al. (2004) indicated that the System Assessment Capability (SAC) (Kincaid et al. 2000; Bryce et al. 2002; Eslinger 2002a, 2002b) would be used for the analysis. They also identified 1,046 waste sites from the 2,730 WIDS sites and several existing and future storage sites for inclusion in the 2004 Composite Analysis. Each of these sites will be handled as an individual release or storage site whenever inventory and release data permit. 
A number of pieces of information, such as the site identification, coordinates, release model, hydrogeologic column (template), remediation action, infiltration class, and the start time and stop time of a simulated problem, are needed for the numerical assessment. The ESD keyword file was designed to contain this common information. Generally, if information is needed by one or more module of the suite of codes used by SAC, it is entered in the ESD keyword file. A number of the ESD keywords are generated from general information on the waste site, its operational/disposal history, and its environmental settings (past, current, and future). To facilitate the generation of these ESD keyword input files, a master spreadsheet termed the Geographic and Operational Site Parameters List (GOSPL) was assembled. It can generally be subdivided into three main sections: Site-Specific Parameters, Model-Specific Instructions, and Remediation/Infiltration Assumptions. This report briefly describes each of the key data fields, including the source(s) of data, and provides the inputs to be used for the 2004 Composite Analysis.

This master spreadsheet was originally developed for the initial assessments conducted using the SAC to lock down the site-specific location and facility design parameters as well as the key model assumptions for each assessment. GOSPL has continued to evolve as the site information and/or assessment basis has changed. It is recommended that a complete restructuring of GOSPL be developed to interactively retrieve data directly from the record databases (e.g., WIDS) and to streamline the selection of sites and model assumptions.

\subsection{References}

BHI. 1998. Hanford Site Atlas. BHI-01119, Rev. 1, Bechtel Hanford Inc., Richland, Washington.

Bryce RW, CT Kincaid, PW Eslinger, and LF Morasch (eds.). 2002. An Initial Assessment of Hanford Impact Performed with the System Assessment Capability. PNNL-14027, Pacific Northwest National Laboratory, Richland, Washington.

Cantrell KJ, RJ Serne, and GV Last. 2003a. Hanford Contaminant Distribution Coefficient Database and Users Guide. PNNL-13895, Rev. 1, Pacific Northwest National Laboratory, Richland, Washington.

Cantrell KJ, RJ Serne, and GV Last. 2003b. Applicability of the Linear Sorption Isotherm Model to Represent Contaminant Transport Processes in Site-Wide Performance Assessments - A White Paper. CP-17089, Fluor Hanford, Inc., Richland, Washington.

Comprehensive Environmental Response, Compensation, and Liability Act. 1980. Public Law 96-150, as amended, 94 Stat. 2767, 42 USC 9601 et seq.

DOE. 2003. Hanford Site Waste Management Units Report. DOE/RL-88-30, Rev. 12, U.S. Department of Energy, Richland, Washington

(http://apweb02.rl.gov/rapidweb/phmc/cp/wids/index2.cfm.cfm?FileName=/docs/5/docs/Rl88-30_R11.pdf) 
DOE Order 435.1. 1999. Radioactive Waste Management. U.S. Department of Energy, Washington, D.C. Available on the Internet at http://www.hanford.gov/wastemgt/doe/psg/pdf/doe0435.pdf

Eslinger PW, DW Engel, LH Gerhardstein, CA Lo Presti, WE Nichols, and DL Strenge. 2002a. User Instructions for the Systems Assessment Capability, Rev. 0, Computer Codes, Volume 1: Inventory, Release, and Transport Modules. PNNL-13932, Volume 1, Pacific Northwest National Laboratory, Richland, Washington.

Eslinger PW, C Arimescu, DW Engel, BA Kanyid, and TB Miley. 2002b. User Instructions for the Systems Assessment Capability, Rev. 0, Computer Codes, Volume 2: Impacts Modules. PNNL-13932, Volume 2, Pacific Northwest National Laboratory, Richland, Washington.

Hajek BF. 1966. Soil Survey Hanford Project in Benton County, Washington. BNWL-243, Pacific Northwest Laboratory, Richland, Washington.

Kincaid CT, MP Bergeron, CR Cole, MD Freshley, NL Hassig, VG Johnson, DI Kaplan, RJ Serne, GP Streile, DL Strenge, PD Thorne, LW Vail, GA Whyatt, and SK Wurstner. 1998. Composite Analysis for Low-Level Waste Disposal in the 200 Area Plateau of the Hanford Site. PNNL-11800, Pacific Northwest National Laboratory, Richland, Washington.

Kincaid CT, PW Eslinger, WE Nichols, AL Bunn, RW Bryce, TB Miley, MC Richmond, SF Snyder, and RL Aaberg. 2000. Groundwater/Vadose Zone Integration Project, System Assessment Capability (Revision 0), Assessment Description, Requirements, Software Design, and Test Plan. BHI-01365, Draft A, Bechtel Hanford, Inc., Richland, Washington.

Kincaid CT, RW Bryce, and JW Buck. 2004. Technical Scope and Approach for the 2004 Composite Analysis of Low-Level Waste Disposal at the Hanford Site. PNNL-14372, Pacific Northwest National Laboratory, Richland, Washington.

Last GV, EJ Freeman, KJ Cantrell, MJ Fayer, GW Gee, WE Nichols, and BN Bjornstad. 2004. Vadose Zone Hydrogeology Data Package for the 2004 Composite Analysis. PNNL-14702, Rev. 0, Pacific Northwest National Laboratory, Richland, Washington.

Mann FM. 2003. Annual Summary of the Immobilized Low-Activity Waste Performance Assessment for 2003, Incorporating the Integrated Disposal Facility Concept. DOE/ORP-2000-19, Revision 3, U.S. Department of Energy, Richland, Washington.

Maxfield HL. 1979. Handbook - 200 Areas Waste Sites. RHO-CD-673, Volumes I, II, and III, Rockwell Hanford Operations, Richland, Washington.

Resource Conservation and Recovery Act. 1976. Public Law 94-580, as amended, 90 Stat. 2795, 42 USC 6901 et seq.

Riley RG and C Lo Presti. 2004. Release Model Data Package for the 2004 Composite Analysis. PNNL-14760, Rev. 0, Pacific Northwest National Laboratory, Richland, Washington. 


\section{Appendix}

Geographic and Operational Site Parameters for Waste Sites To Be Simulated in the 2004 Composite Analysis 
Geographic and Operational Site Parameters for Waste Sites To Be Simulated in the 2004 Composite Analysis

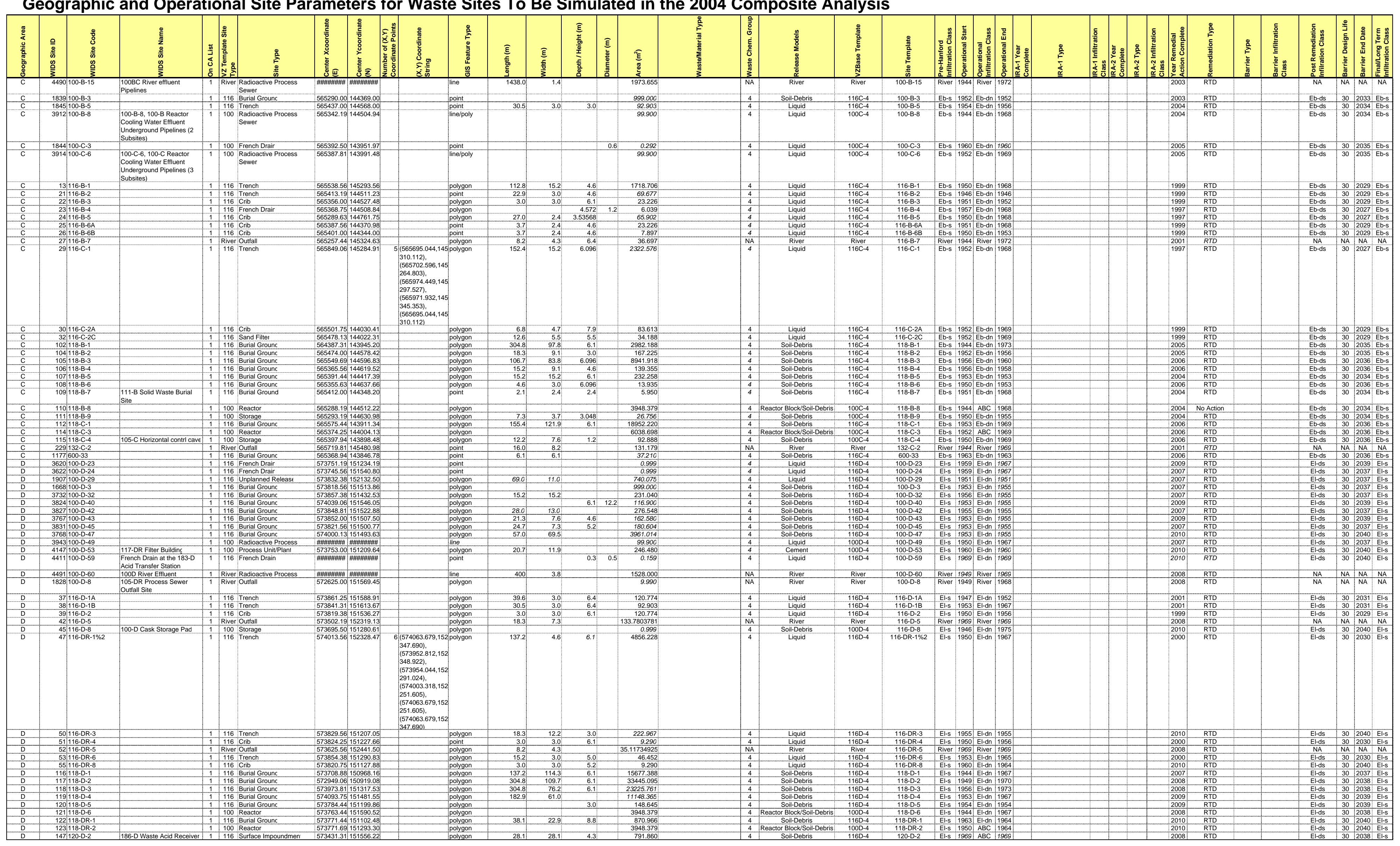


Geographic and Operational Site Parameters for Waste Sites To Be Simulated in the 2004 Composite Analysis

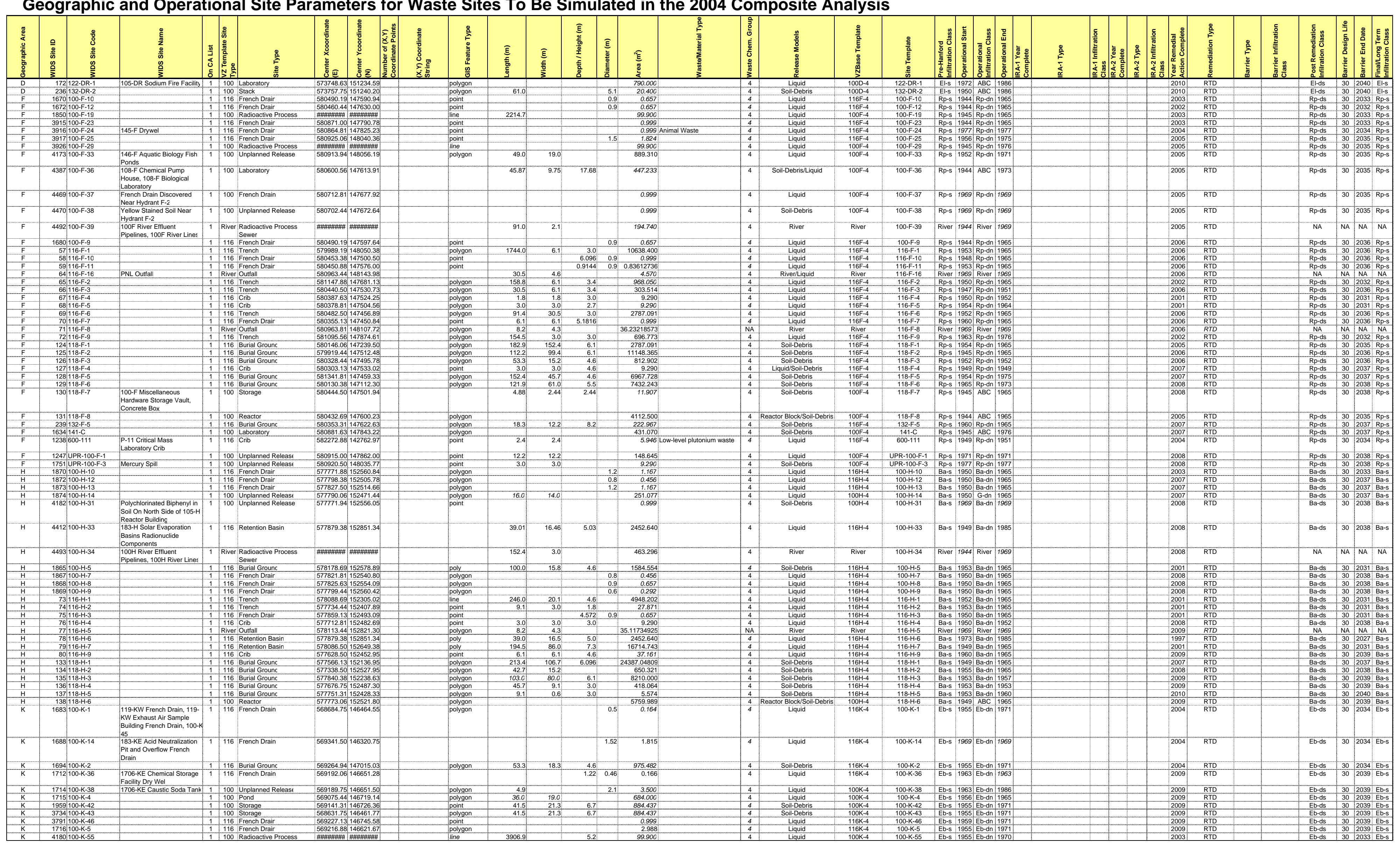


Geographic and Operational Site Parameters for Waste Sites To Be Simulated in the 2004 Composite Analysis

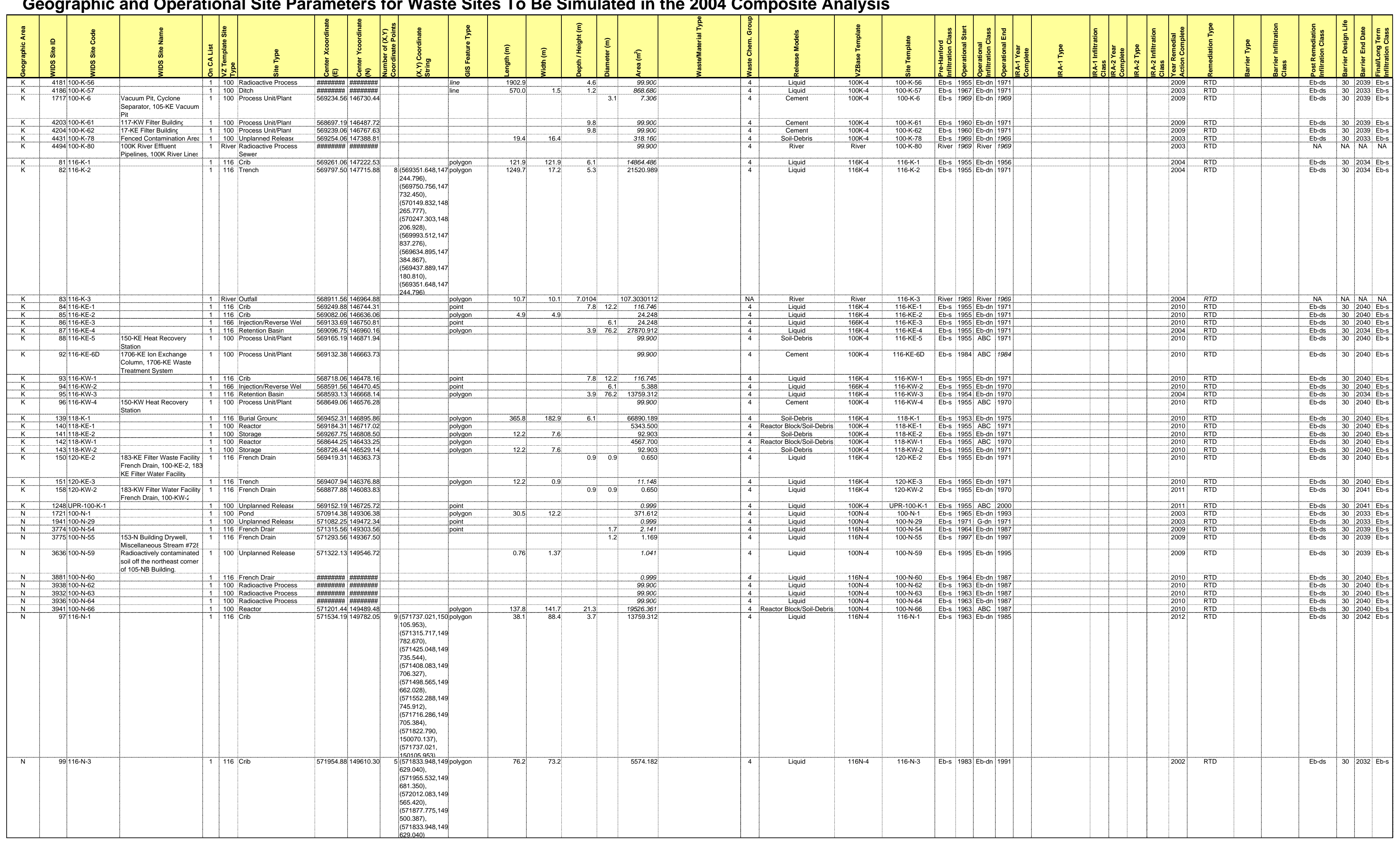


Geographic and Operational Site Parameters for Waste Sites To Be Simulated in the 2004 Composite Analysis

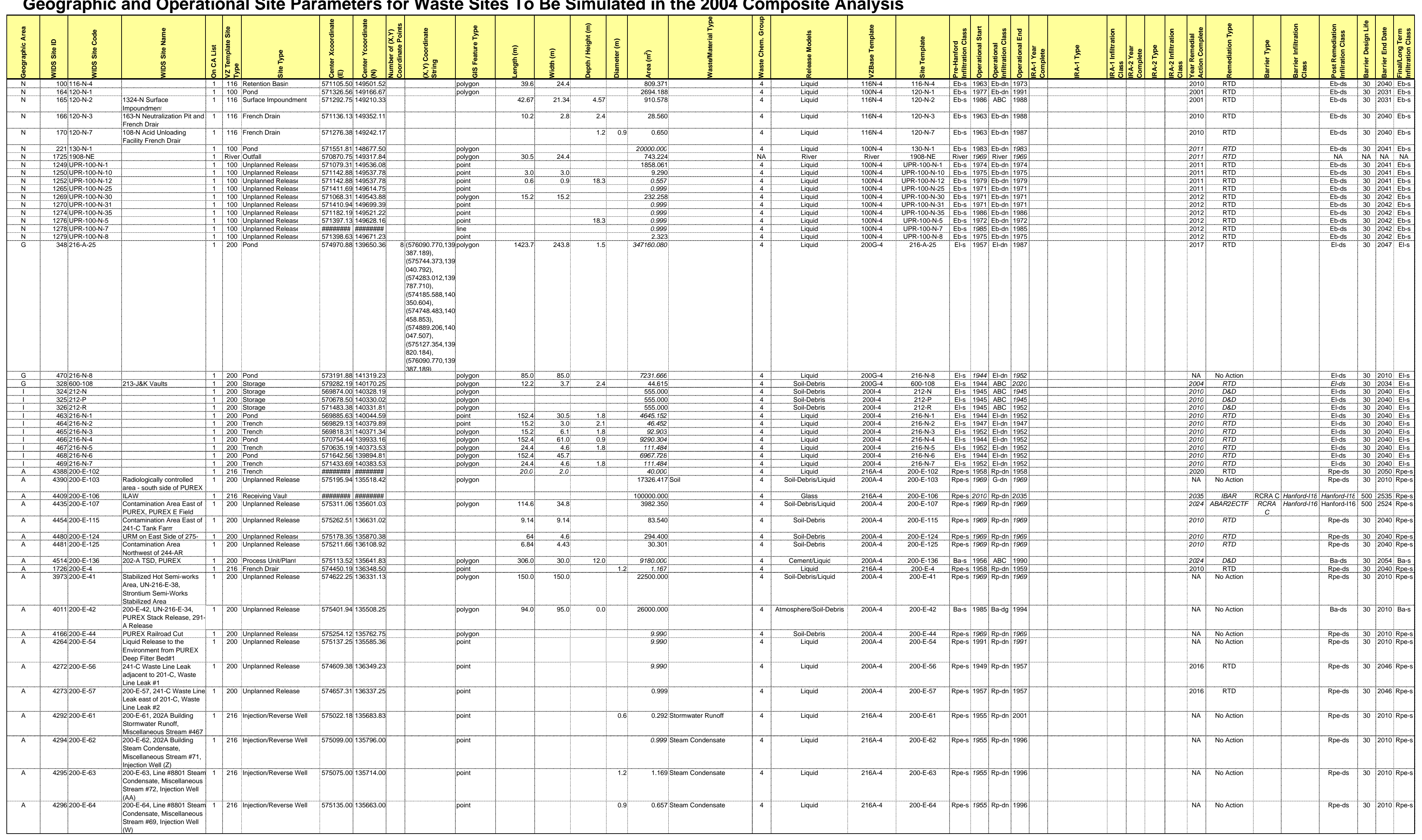


Geographic and Operational Site Parameters for Waste Sites To Be Simulated in the 2004 Composite Analysis

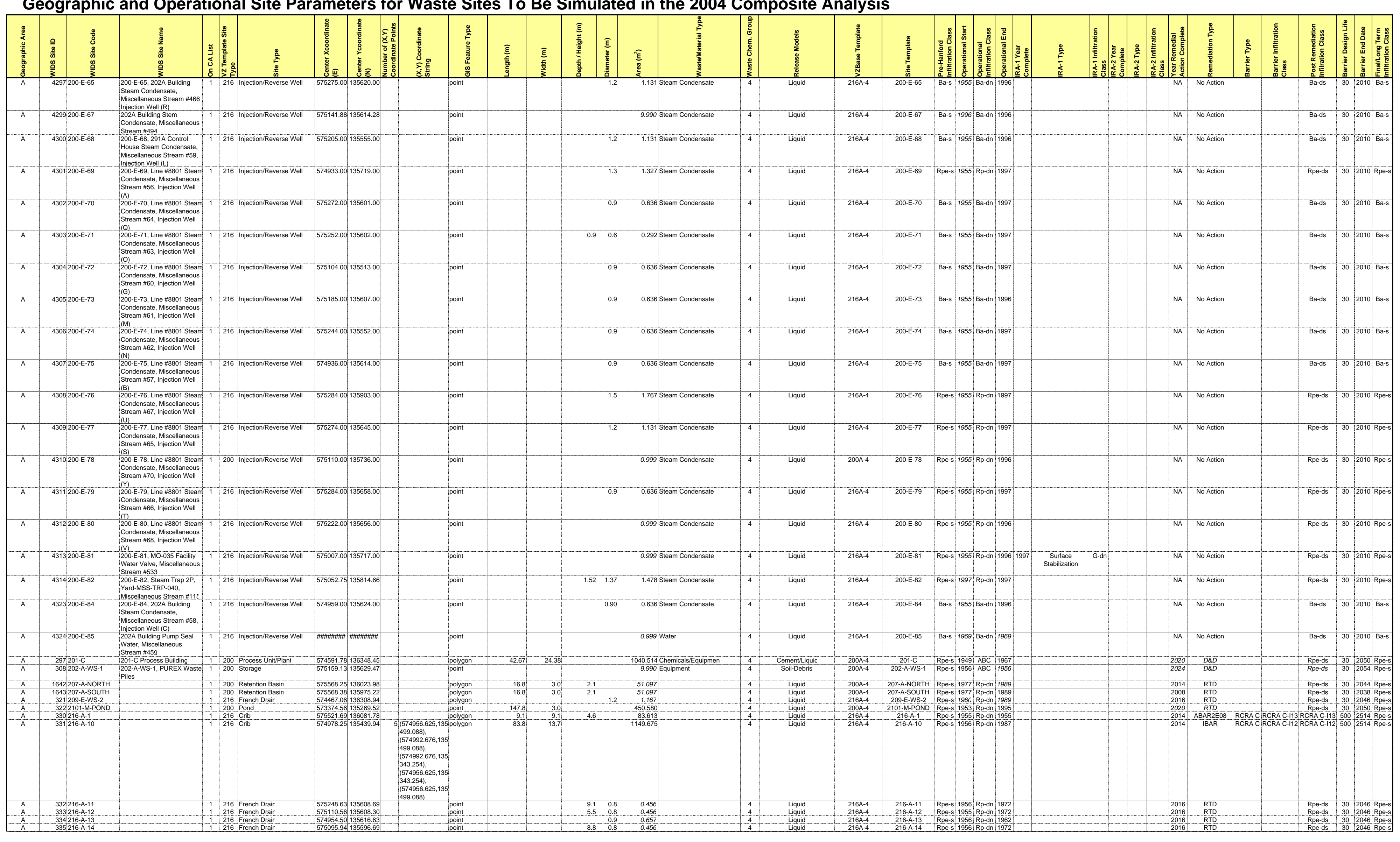


Geographic and Operational Site Parameters for Waste Sites To Be Simulated in the 2004 Composite Analysis

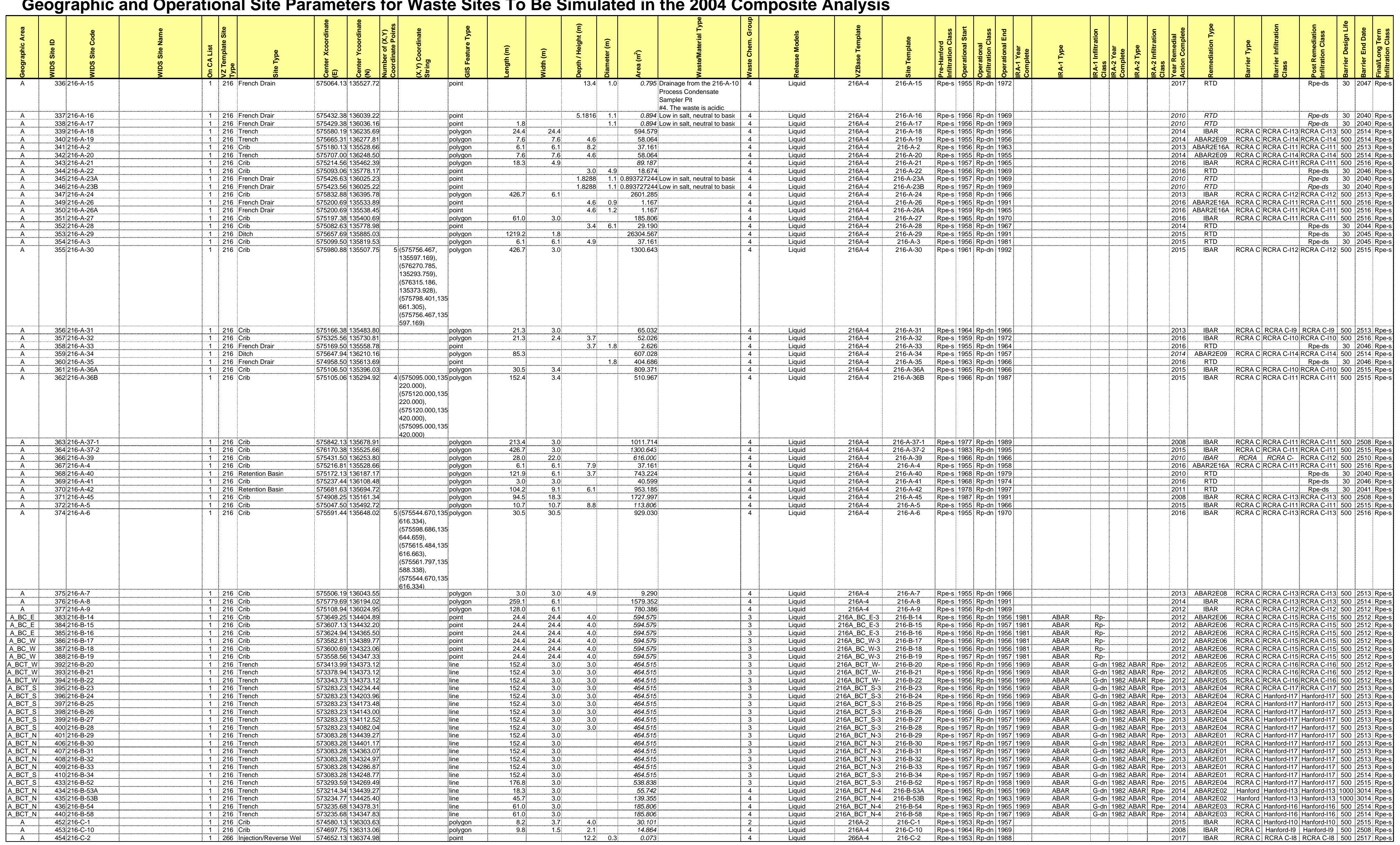


Geographic and Operational Site Parameters for Waste Sites To Be Simulated in the 2004 Composite Analysis

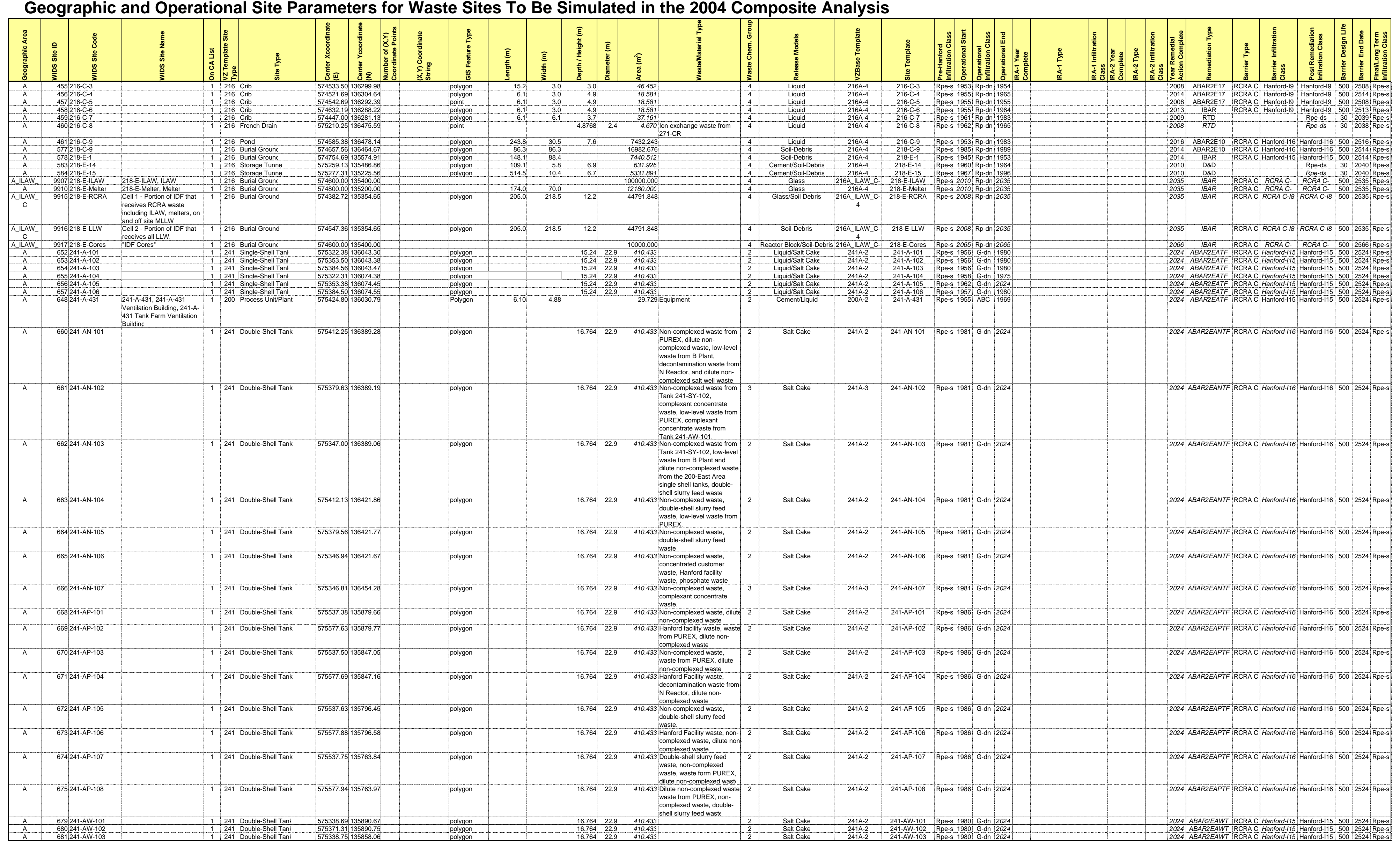


Geographic and Operational Site Parameters for Waste Sites To Be Simulated in the 2004 Composite Analysis

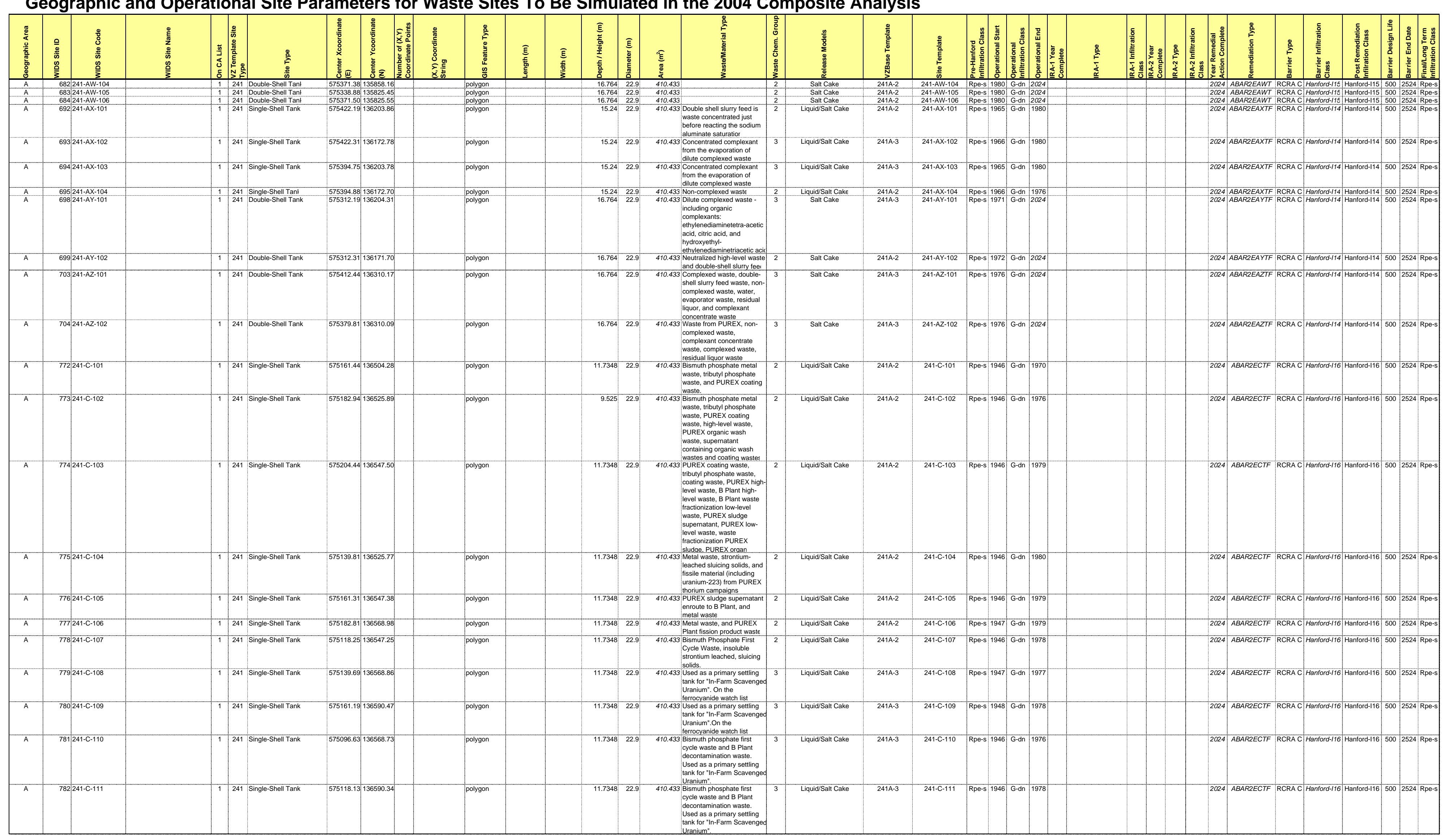


Geographic and Operational Site Parameters for Waste Sites To Be Simulated in the 2004 Composite Analysis

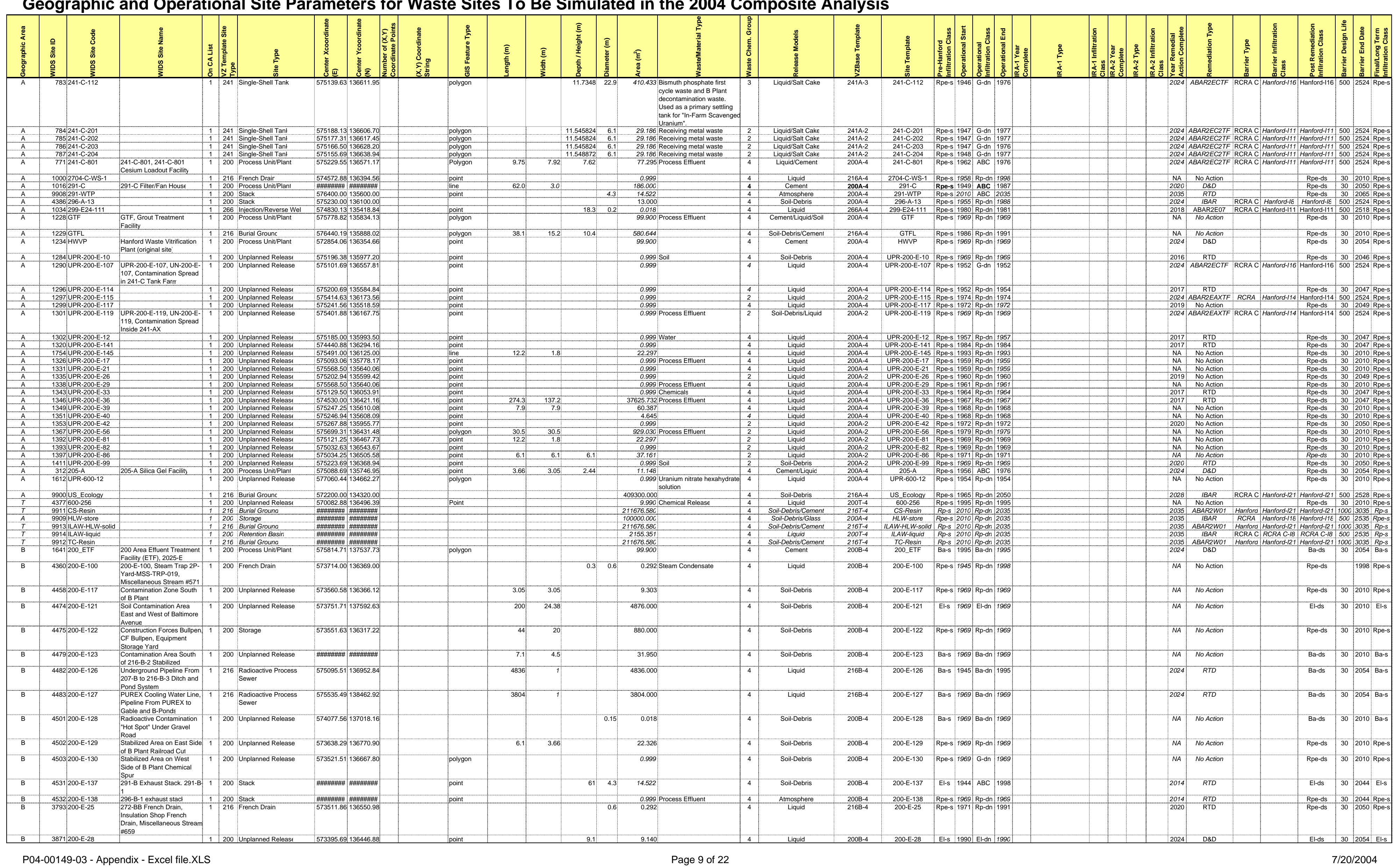


Geographic and Operational Site Parameters for Waste Sites To Be Simulated in the 2004 Composite Analysis

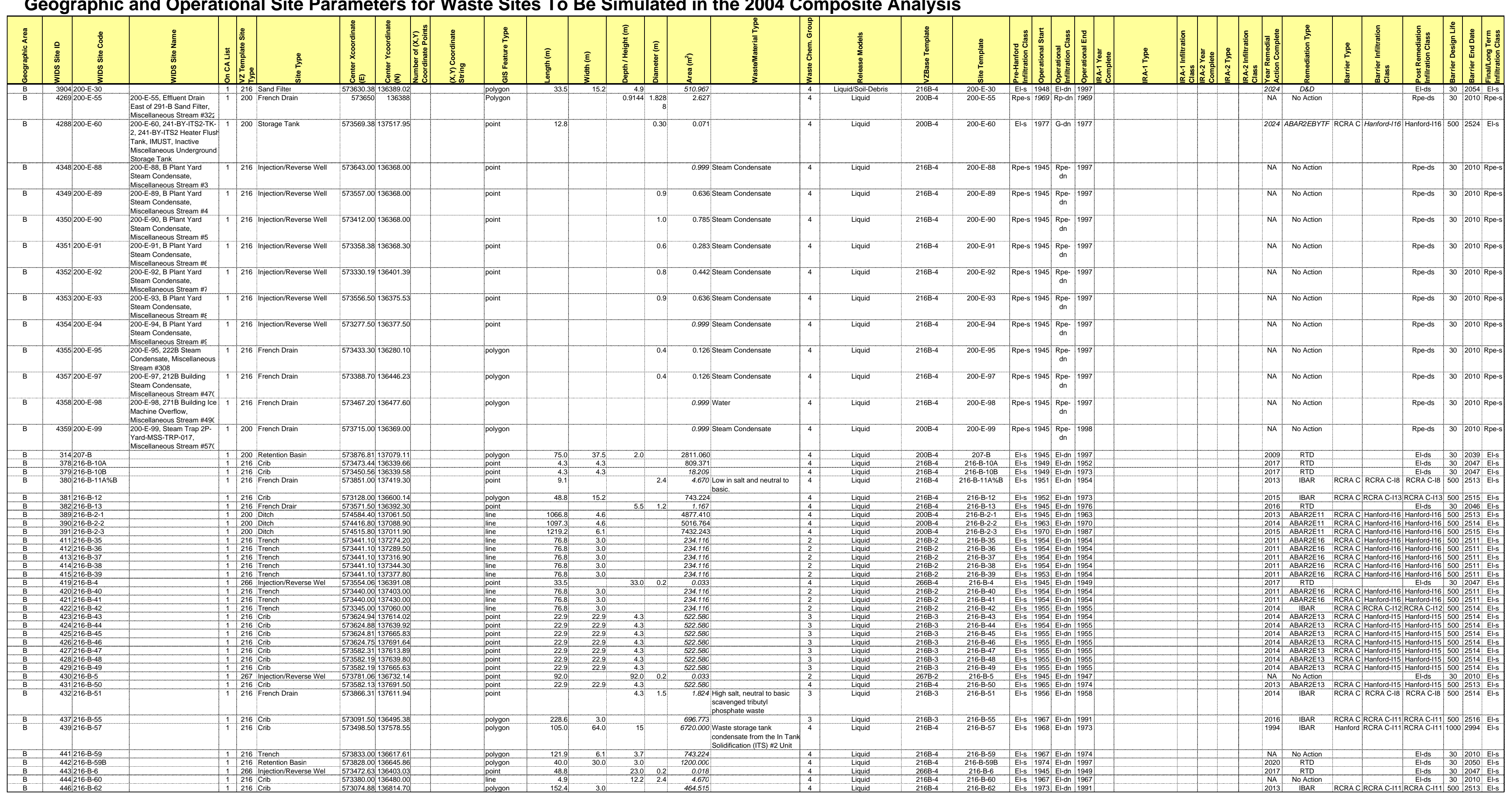


Geographic and Operational Site Parameters for Waste Sites To Be Simulated in the 2004 Composite Analysis

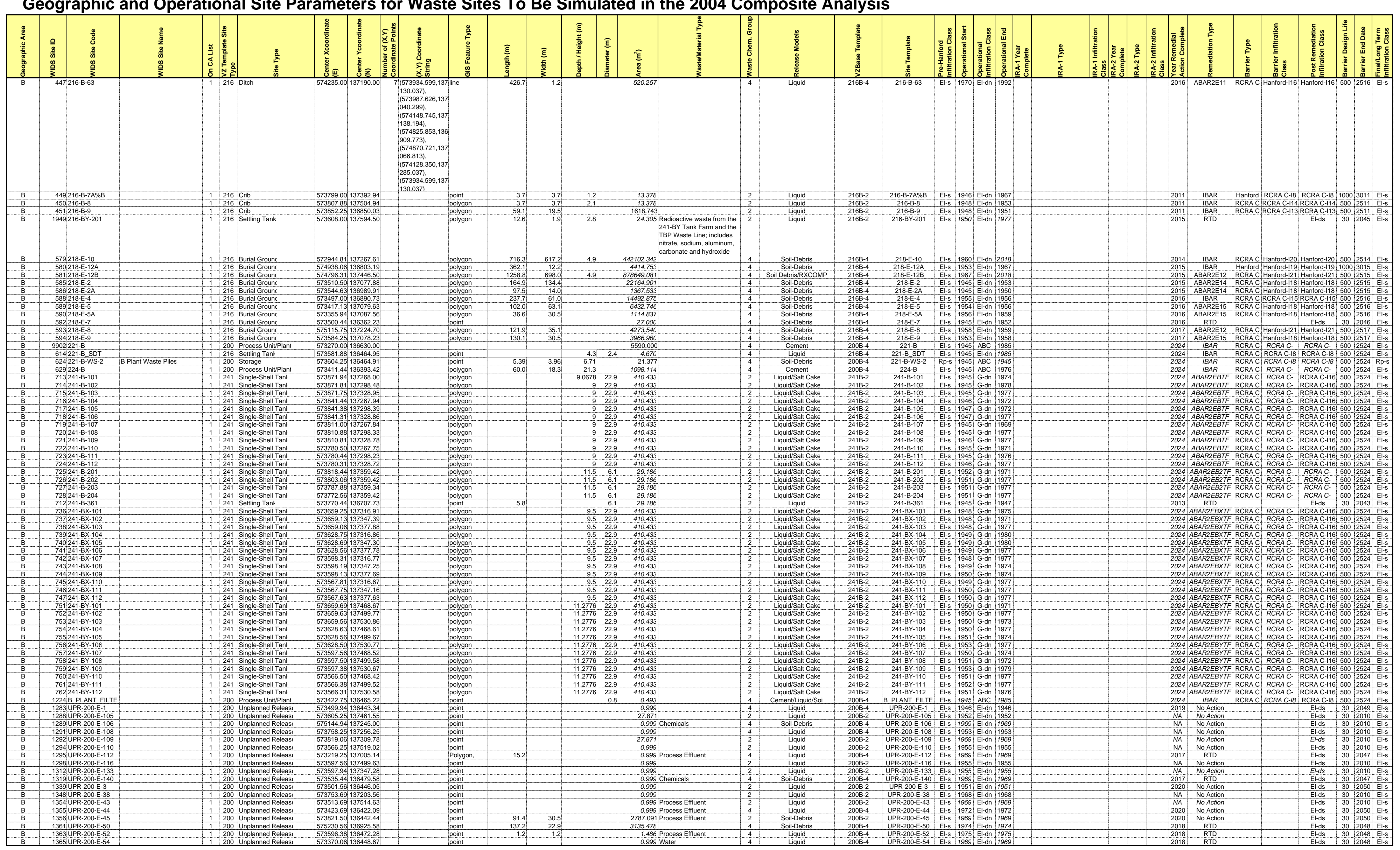


Geographic and Operational Site Parameters for Waste Sites To Be Simulated in the 2004 Composite Analysis

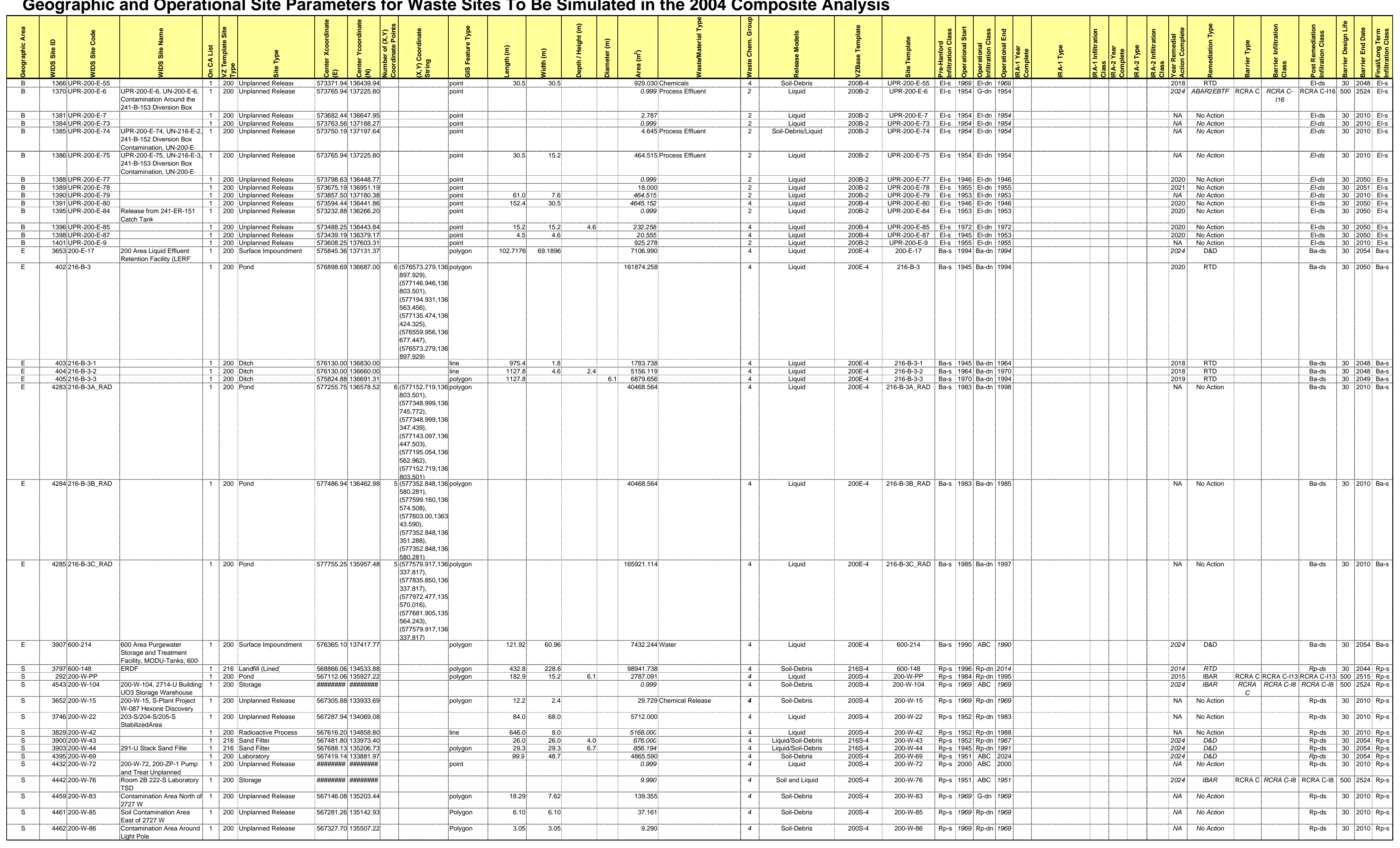


Geographic and Operational Site Parameters for Waste Sites To Be Simulated in the 2004 Composite Analysis

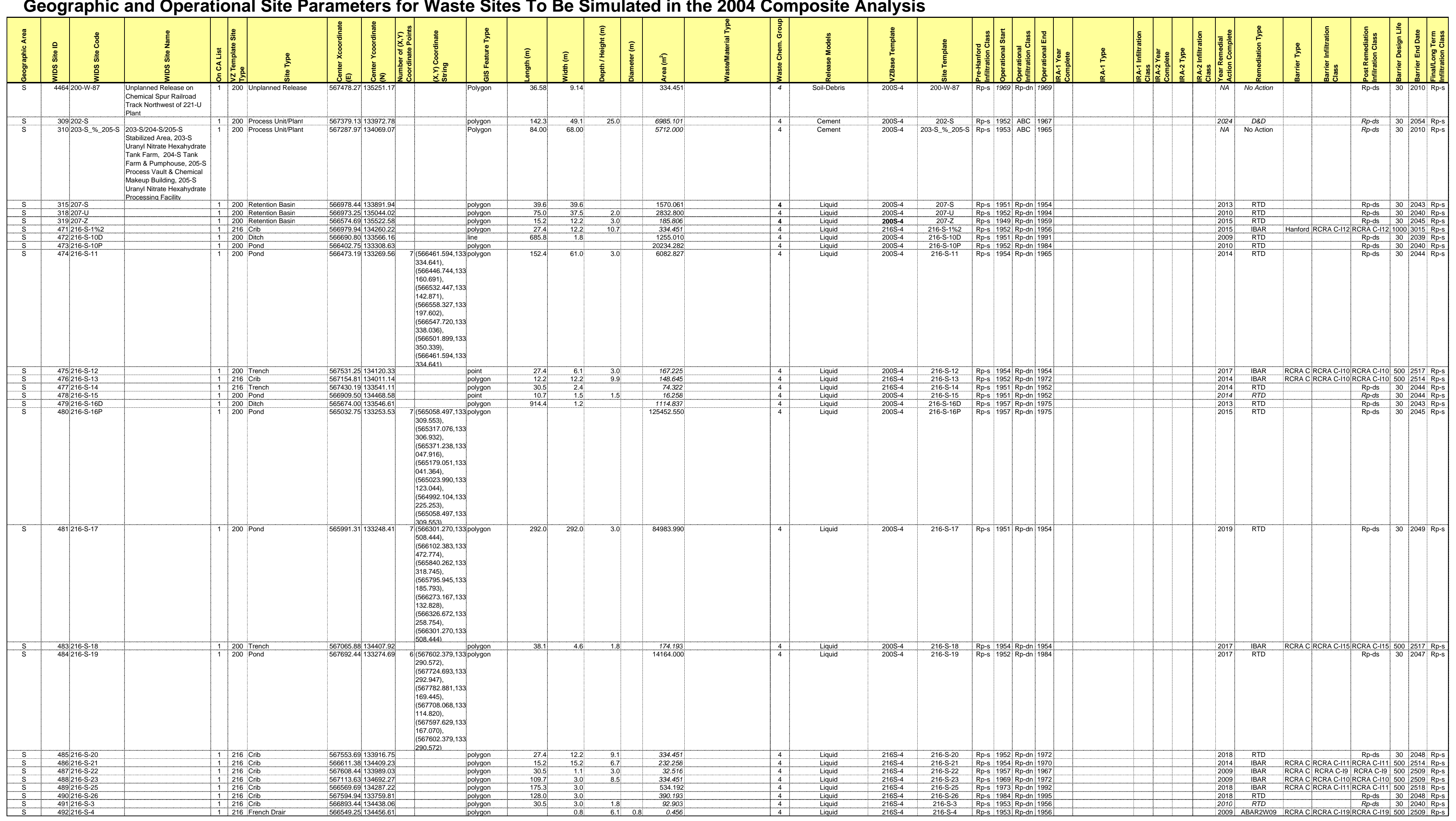




\section{Geographic and Operational Site Parameters for Waste Sites To Be Simulated in the 2004 Composite Analysis}

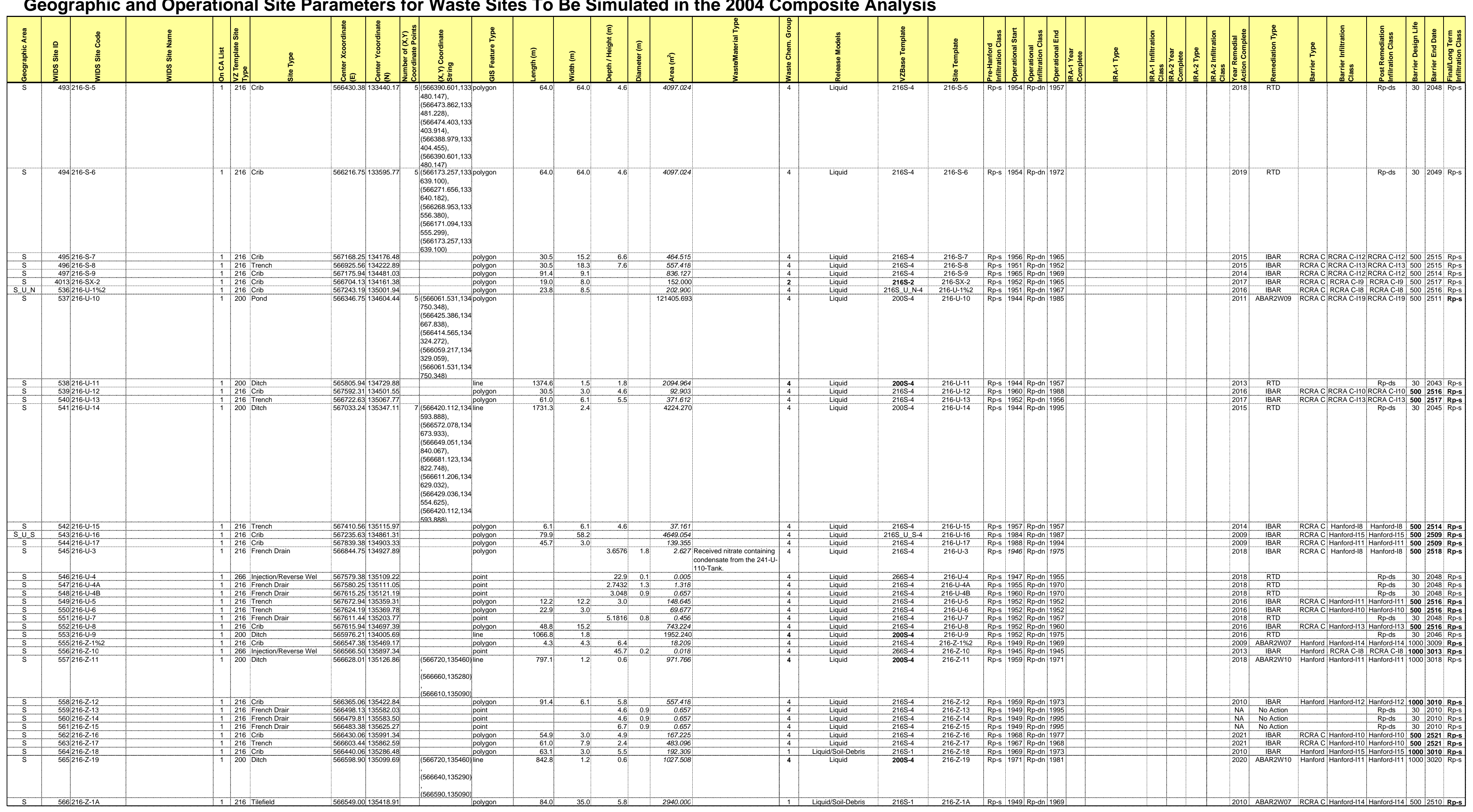


Geographic and Operational Site Parameters for Waste Sites To Be Simulated in the 2004 Composite Analysis

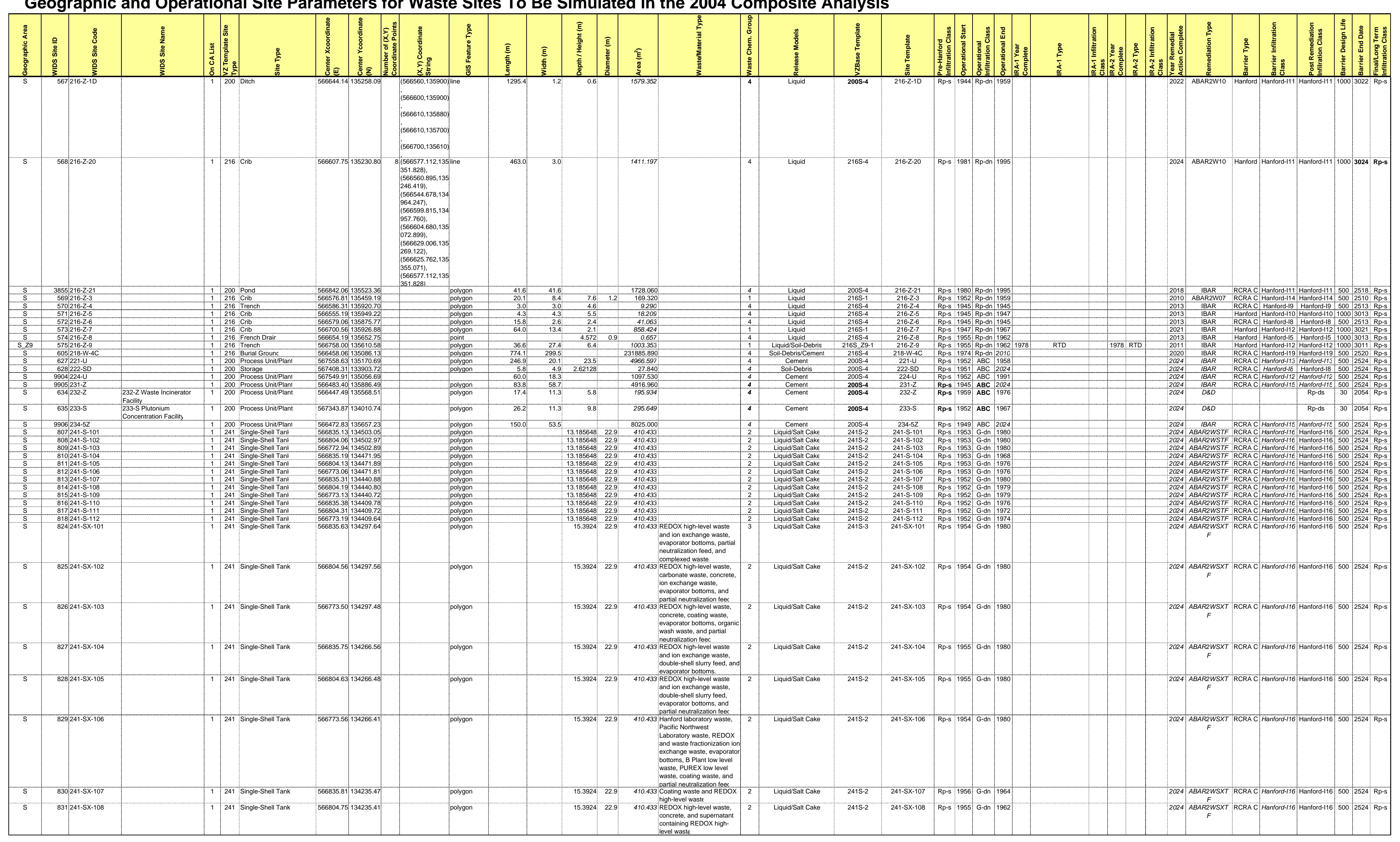


Geographic and Operational Site Parameters for Waste Sites To Be Simulated in the 2004 Composite Analysis

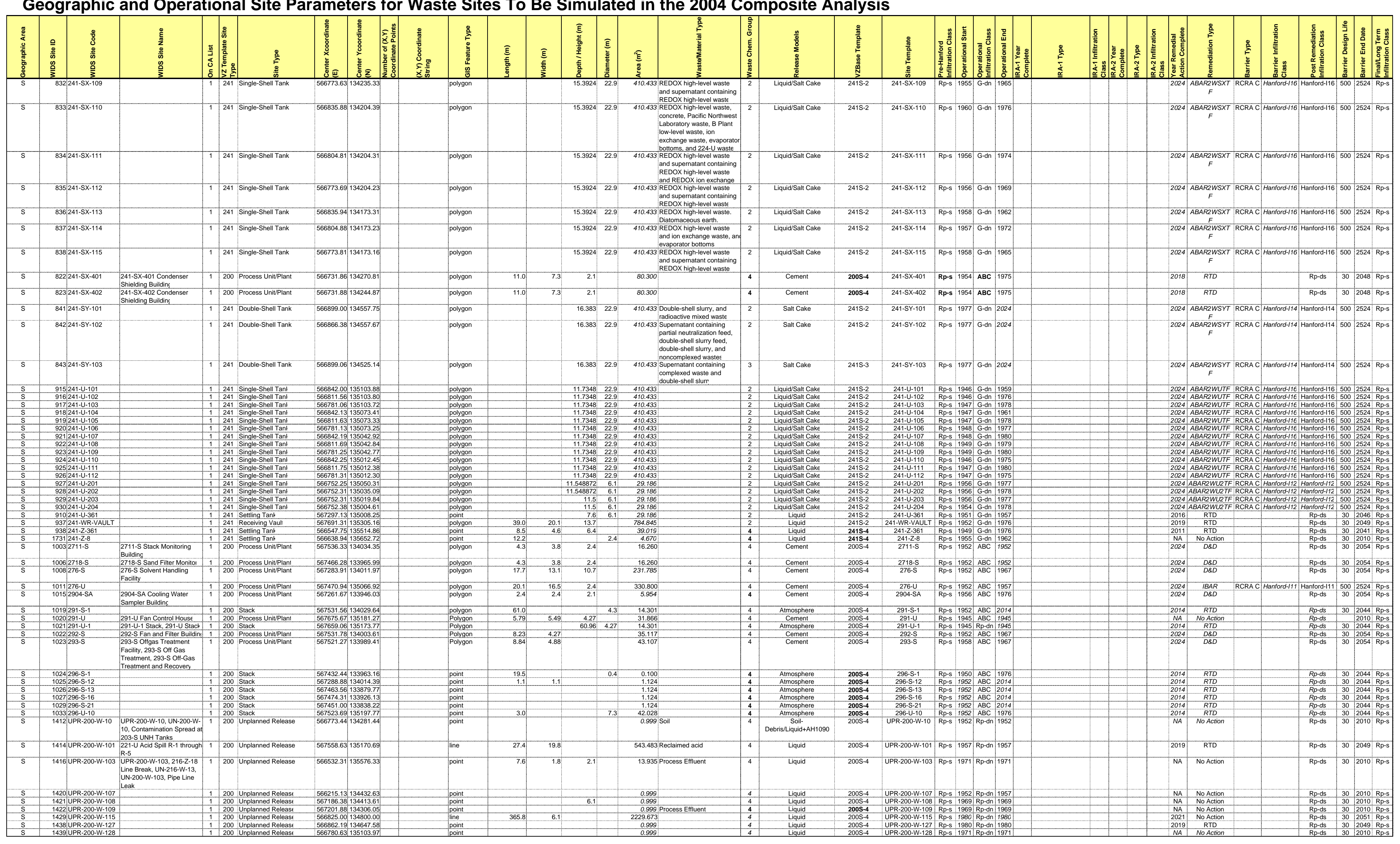


Geographic and Operational Site Parameters for Waste Sites To Be Simulated in the 2004 Composite Analysis

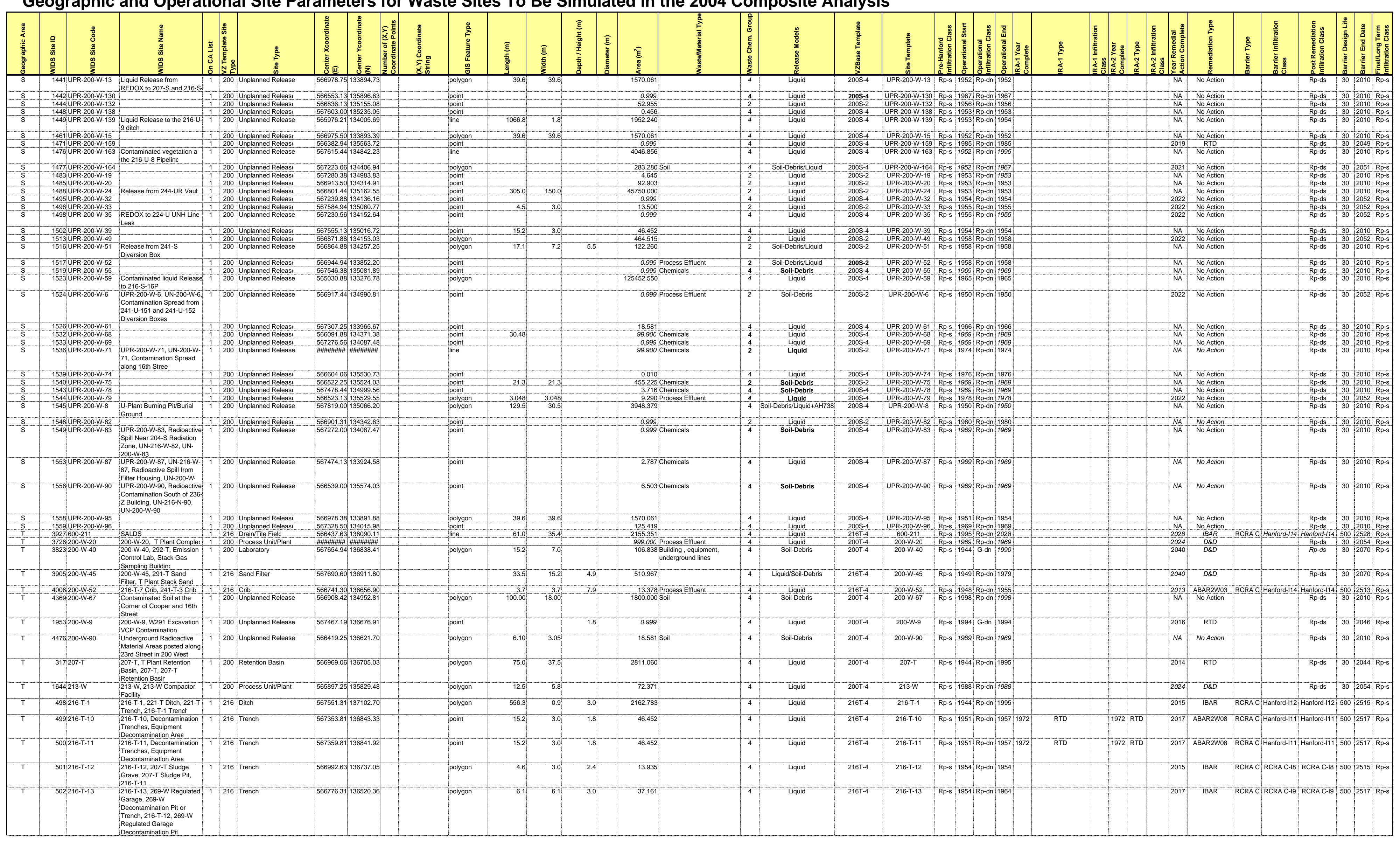


Geographic and Operational Site Parameters for Waste Sites To Be Simulated in the 2004 Composite Analysis

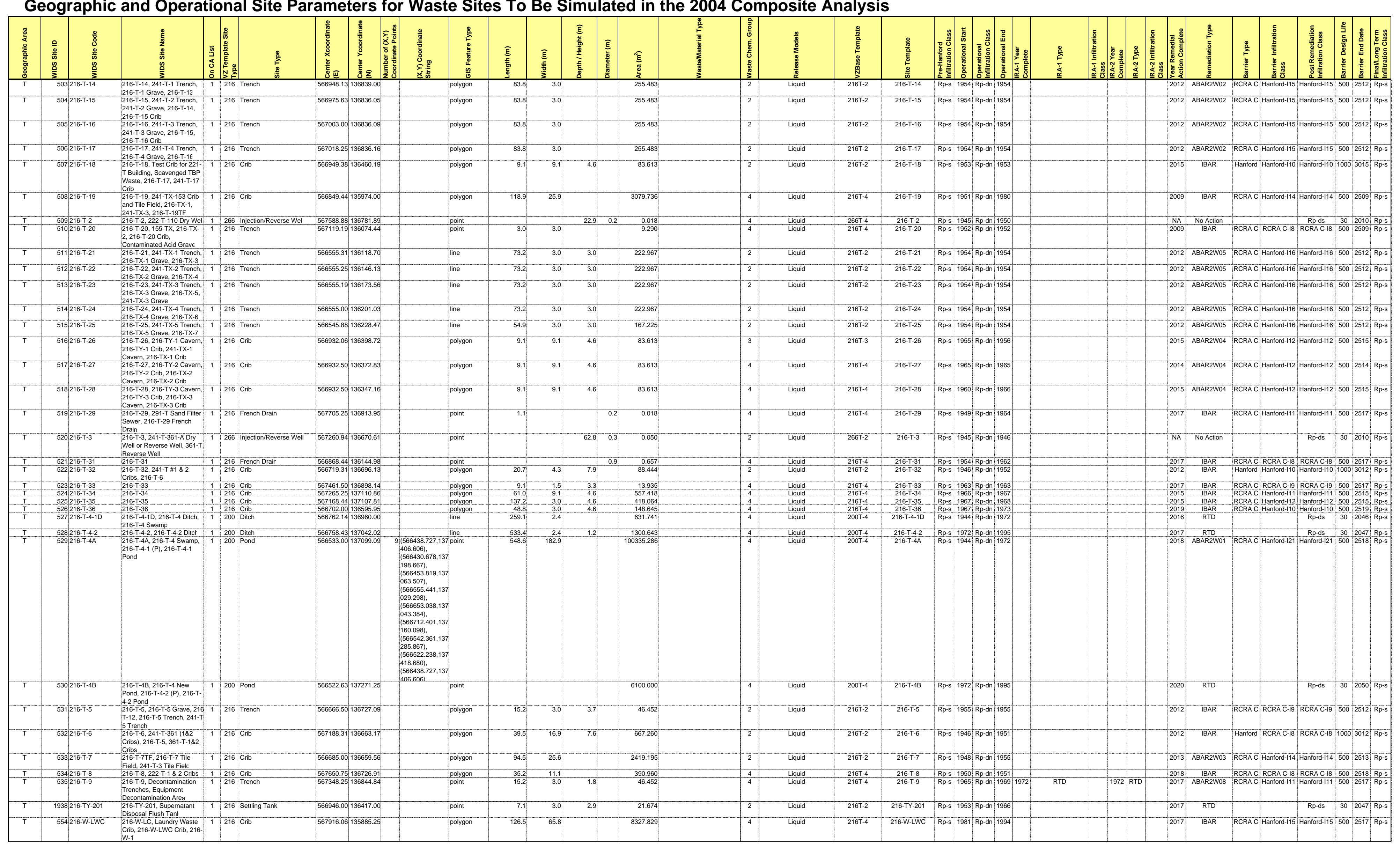


Geographic and Operational Site Parameters for Waste Sites To Be Simulated in the 2004 Composite Analysis

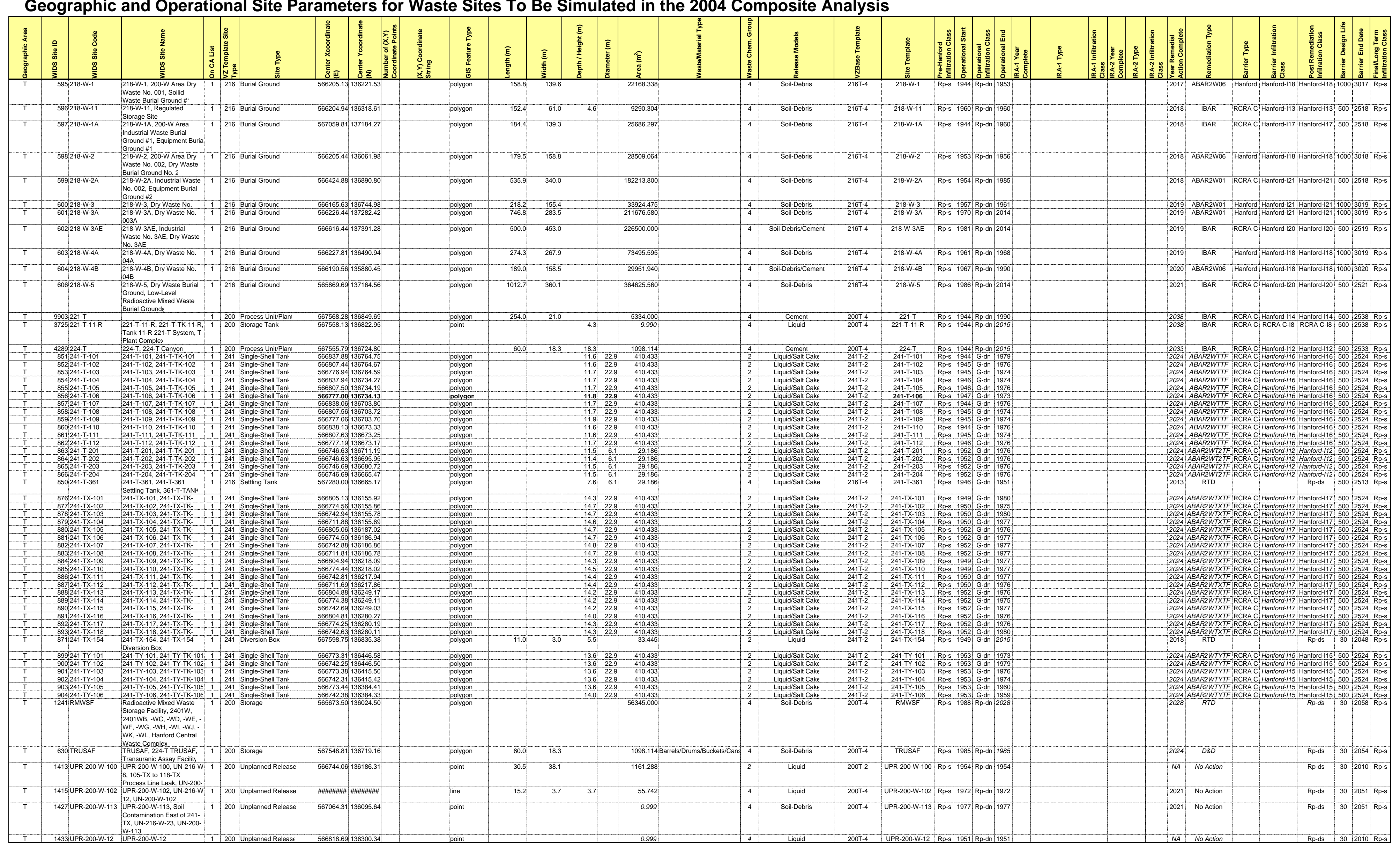


Geographic and Operational Site Parameters for Waste Sites To Be Simulated in the 2004 Composite Analysis

\begin{tabular}{|c|c|c|c|c|c|c|c|c|c|c|c|c|c|c|c|c|c|c|c|c|c|c|c|c|c|c|c|c|c|c|c|c|c|c|}
\hline 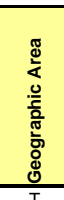 & 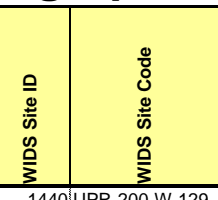 & 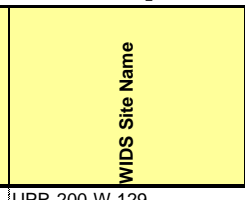 & 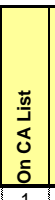 & | & 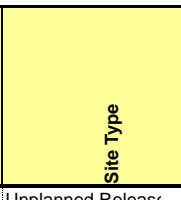 & 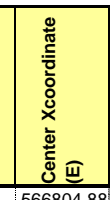 & 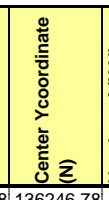 & 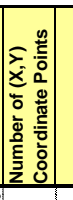 & 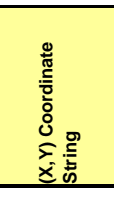 & 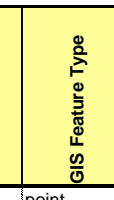 & 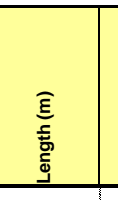 & $\begin{array}{l}\bar{E} \\
\text { 䇏 } \\
\end{array}$ & 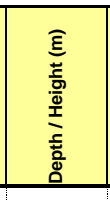 & 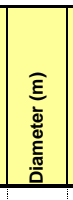 & 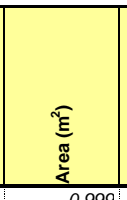 & 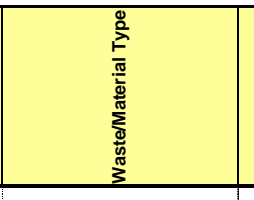 & 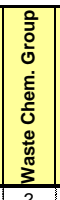 & 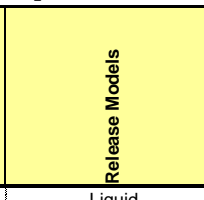 & 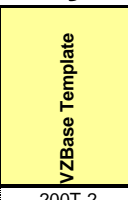 & 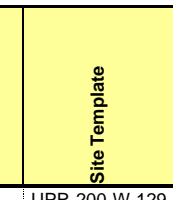 & 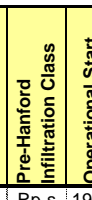 & 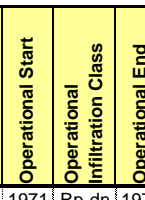 & 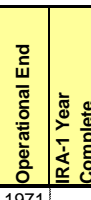 & || & 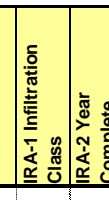 & 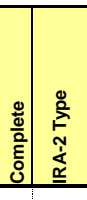 & $\mid$ & 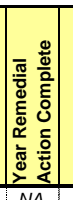 & 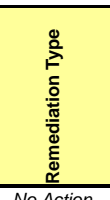 & 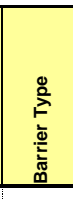 & 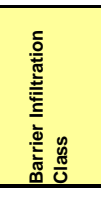 & 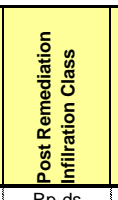 & 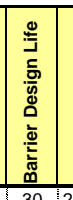 & 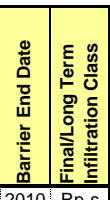 \\
\hline${ }_{T}^{T}$ & 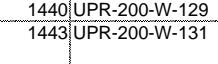 & 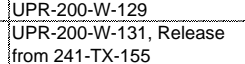 & $\frac{1}{1}$ & 2000 & 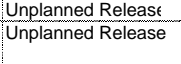 & $\begin{array}{l}566870.480 \\
550150\end{array}$ & 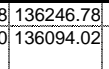 & & & $\begin{array}{l}\text { point } \\
\text { point }\end{array}$ & & & & & $\begin{array}{l}0.999 \\
0.999 \\
\end{array}$ & & 4 & $\begin{array}{l}\text { Liquid } \\
\text { Liquid } \\
\end{array}$ & $\begin{array}{l}\frac{200 T-2}{200 T-4} \\
\end{array}$ & $\begin{array}{l}\text { UPR-200-W-129 } \\
\text { UPR-200-W-W-131 }\end{array}$ & $\begin{array}{l}\text { Rp-s } 19 \\
\text { Rp.s } 19 \\
\end{array}$ & $\begin{array}{l}1971 \text { Rp-dd } 19 \\
1953 \text { Rp-dn } 19 \\
\end{array}$ & $\frac{1971}{1953}$ & & & & & $\frac{N A}{2021}$ & 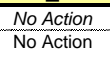 & & & 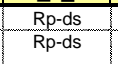 & 302 & 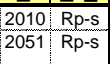 \\
\hline $\mathrm{T}$ & 1445 UPR-200-W-134 & 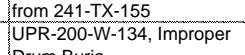 & 1 & 2004 & Unplanned Release & 566241.19 & 9136258.17 & & & point & & & & & 0.999 & 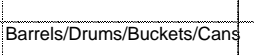 & 54 & Soil-Debris & $2000-4$ & UPR-200-W-134 & Rp-s 19 & 1975 Rp-dn 19 & 1975 & & & & & $\mathrm{NA}$ & No Accion & & & Rp-ds & 302 & 2010 Rp.s \\
\hline T & 1446 UPR-200-W-135 & 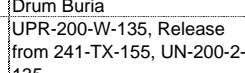 & & 2004 & Unplanned Release & 5671119.19 & 9336074.44 & & & point & 12.2 & & & & 0.999 & & 2 & Liquid & $2007-2$ & UPR-200-W-135 & Rp-s 19 & 1954 Rp-dn 199 & 1954 & & & & & 2021 & No Action & & & Rp-ds & 302 & 2051 Rp.s \\
\hline $\mathrm{T}^{\mathrm{T}}$ & 1450 UPR-200-W-14 & 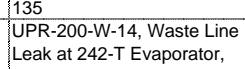 & 1 & 2004 & Unplanned Release & 566938.25 & 5 5136540.31 & & & point & & & & & 0.999 & & 4 & Liquid & $2007-4$ & UPR-200-W-14 & Rp.s 19 & 1952 Rp-dn 19: & 1952 & & & & & 2019 & RTD & & & Rp-ds & 302 & 2049 Rp-s \\
\hline & 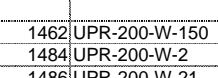 & 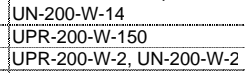 & & $200 \mathrm{i}$ & $\begin{array}{l}\text { Unplanned Release } \\
\text { Unplanned Releast }\end{array}$ & 567520.00 & 0.13674500 & & & $\begin{array}{c}\text { point } \\
\text { point }\end{array}$ & & & & & 0.0999 & & 4 & $\begin{array}{l}\text { Liquid } \\
\text { Liquid }\end{array}$ & $\begin{array}{l}2007-2 \\
2007-4\end{array}$ & & & & & & & & & $\frac{2024}{2021}$ & $\begin{array}{l}\text { IBAR } \\
\text { No Dacition }\end{array}$ & RCPA & & $\begin{array}{l}\text { RCRAC-1 } \\
\text { Rpo-ds }\end{array}$ & & \\
\hline & 1486 UPR-200-W-21 & 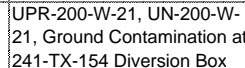 & & 2004 & Unplanned Release & 5675777.75 & 5136822.78 & & & point & 48.8 & 27.4 & & & 1337.804 & & 2 & Liquid & $200 T-2$ & & $\begin{array}{lll}p p-s & 19\end{array}$ & 醇 19: & & & & & & & No A Action & & & 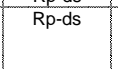 & 302 & \\
\hline & 1991 UPP-200-W-28 & 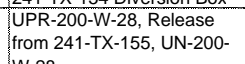 & 1 & 2004 & Unplanned Release & 567064.19 & 9136107.53 & & & point & 30.5 & 9.1 & & & 278.709 & & 2 & Liquid & $200 T-2$ & UPP-200-W-28 & $R p-s 19$ & 1954 Rp-dn 19: & 1954 & & & & & 2021 & No Action & & & Rp-ds & 302 & \\
\hline$T^{T}$ & 1492 UPR-200-W-29 & 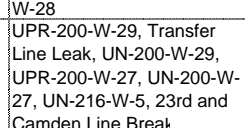 & 1 & 2004 & Unplanned Release & 566907.88 & 8336595.58 & & & polygon & 30.5 & 22.9 & & & 696.773 & & 2 & Liquid & $200 T-2$ & UPR-200-W-29 & Rp-s 19 & 1954 G-dn $19:$ & 1954 & & & & & 2022 & No Action & & & Rp-ds & 302 & 2052 Rp.s \\
\hline $\mathrm{T}^{\mathrm{T}}$ & 1501 UPR-200-W-38 & 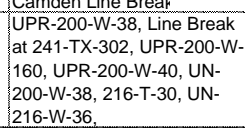 & & 2004 & Unplanned Release & 567603.00 & 0136840.58 & & & point & & & & & 371.612 & & 2 & Liquid & $2007-2$ & UPR-200-W-38 & Rp-s 19 & 1955 Rp-dn $19:$ & 1955 & & & & & 2022 & No Action & & & Rp-ds & 302 & 2052 Rp.s \\
\hline $\mathrm{T}$ & 1508 UPP-200-W-44 & 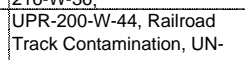 & 1 & 200 & Unplanned Release & 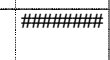 & 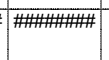 & & & & 7.6 & 6.1 & & & $46.452:$ & & 4 & Soli-Debris & $200 T-4$ & UPR-200-W-44 & $R p-519$ & 1954 Rp-dn 19 & 1954 & & & & & $\mathrm{NA}$ & No Action & & & Rp-ds & 302 & 2010 Rp.s \\
\hline$T^{T}$ & 1514 UPR-200-W.-5 & 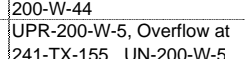 & 1 & 200 & Unplanned Release & 567064.31 & 133088.02 & & & point & & & & & 0.999 & & 2 & Liquid & $2007-2$ & UPR-200-W-5 & Rp.S 19 & 1950 Rp-dn $19:$ & 1950 & & & & & 2022 & No action & & & Rp-ds & 302 & 2052 Rp.s \\
\hline$T^{\top}$ & 1551 UPR-200-W-S5 & 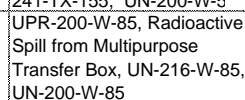 & 1 & 2004 & Unplanned Release & 5675131.06 & 6 6136923.69 & & & point & & & & & 0.999 & & 4 & Liquid & $2007-4$ & UPR-200-W- -85 & $R p \cdot s 19$ & 1982 ABC 19 & & & & & & NA & No Action & & & Rpds & 302 & 2010 Rp-s \\
\hline 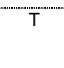 & 1554 UPR-200-W-88 & 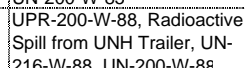 & 1 & 2000 & Unplanned Release & 568024.44 & $\begin{array}{l}4136021.83 \\
\end{array}$ & & & point & & & & & 0.999 & & 4 & Liquid & $2007-4$ & UPR-200-W-88 & Rp-s 19 & 1984 ABC 198 & 1984 & & & & & NA & No Action & & & Rp-ds & 302 & 2010 Rp-S \\
\hline & 1560 UPR-200-W-97 & 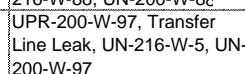 & & 2004 & Unplanned Release & 566902.81 & 1 136559.44 & & & point & & & & & 0.999 & & 2 & Liquid & $2007-2$ & UPR-200-W-97 & Rp.s 19 & 1966 G-dn $19 \mathrm{C}$ & 1966 & & & & & 2022 & No Action & & & Rp-ds & 302 & 2052 Rp-s \\
\hline$T^{T}$ & 1561 UPR-200-W-98 & 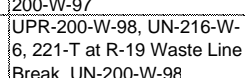 & & 200 & Unplanned Release & 5675150.69 & 9136736.73 & & & point & & & & & 0.999 & & 2 & Liquid & $200 T-2$ & UPR-20-W-98 & Rpps 19 & 1945 Rp-dn 19. & 1945 & & & & & 2022 & No Action & & & Rp-ds & 302 & 2052 Rp-s \\
\hline & 1631 WRAP & 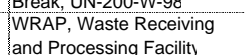 & 1 & 200 & Process Univiplant & 565882.69 & 9136553.25 & & & polygon & 73.2 & 61.0 & & & $4459.346 \mathrm{E}$ & 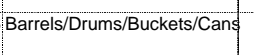 & 54 & Cement & $2007-4$ & WRAP & Rp-s 19 & 1969 Rp-dn 196 & & & & & & 2024 & DED & & & Rp-ds & 302 & 2054 Rp-s \\
\hline $\begin{array}{l}R \\
R \\
R\end{array}$ & 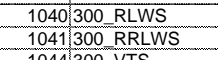 & & $\frac{1}{1}$ & $\begin{array}{l}300 \\
300 \\
300\end{array}$ & 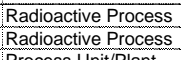 & 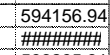 & 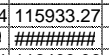 & & & $\begin{array}{l}\text { inine } \\
\text { ine }\end{array}$ & \begin{tabular}{|l|l|}
8535.4 \\
1247.2 \\
\end{tabular} & $\begin{array}{l}0.3 \\
0.3 \\
\end{array}$ & & & $\begin{array}{l}256.0 .022 \\
374.4722\end{array}$ & & $\frac{4}{4}$ & $\begin{array}{l}\text { Liquid } \\
\text { Liquid } \\
\end{array}$ & $\begin{array}{l}3000-4 \\
300 R-4 \\
\end{array}$ & $\begin{array}{l}300 \text { - RLWS } \\
300 \text { RLLWS }\end{array}$ & 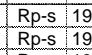 & 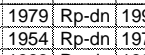 & & & & & & 2004 & $\begin{array}{l}\text { RRD } \\
\text { RTD } \\
\end{array}$ & & & 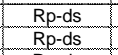 & $\begin{array}{l}302 \\
302 \\
302\end{array}$ & 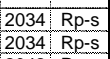 \\
\hline & & 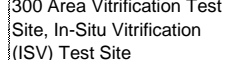 & ${ }^{1}$ & 300 & & 593295.31 & 1116000.06 & & & polygon & & 85.34 & & & & SSoil/Equipment & 4 & & & & & & & & & & & & & & & & & \\
\hline $\mathrm{R}$ & $4052300-121$ & 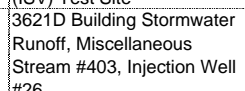 & 1 & 316 & Fiench brain & 594334.75 & 5115664.34 & & & polygon & & & & 1.37 & & & 4 & Liquid & $316 R-4$ & $300-121$ & & & & & & & & 2003 & RTD & & & Rp-ds & 302 & 2033 Rp-s \\
\hline R & 4054 300-123 & 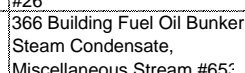 & 1 & 316 & French Drain & 593961.75 & 5 5116052.34 & & & point & & & & 0.69 & 0.369 & Steaan Condensate & 4 & Liquid & $316 \mathrm{R}-4$ & $300-123$ & Rp.s 19 & 1969 Rp-dn 196 & & & & & & 2010 & RTD & & & Rp-ds & 302 & 2040 Rp.S \\
\hline & $\begin{array}{l}115532300-16 \\
.1735300-2 \\
\end{array}$ & & & $\begin{array}{l}300 \\
316 \\
316\end{array}$ & $\begin{array}{l}\text { Unlphanned Releast } \\
\text { Trench }\end{array}$ & $\begin{array}{l}5593775.544 \\
554919\end{array}$ & 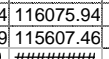 & & & $\begin{array}{l}\text { popint } \\
\text { point }\end{array}$ & & 15.2. & & & 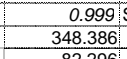 & & & $\begin{array}{l}\text { Soli-Dentis } \\
\text { ciluwid }\end{array}$ & $\begin{array}{l}300 R-4 \\
3168-4 \\
30-4\end{array}$ & $\begin{array}{l}\frac{300-16}{300-2} \\
302\end{array}$ & 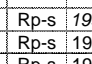 & 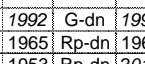 & & & & & & 20054 & $\begin{array}{l}\text { RTD } \\
\text { RTD }\end{array}$ & & & $\begin{array}{l}\frac{R_{p p d s}}{\text { Rppds }} \\
\text { Rpd }\end{array}$ & $\begin{array}{l}30 \\
30\end{array}$ & \\
\hline $\begin{array}{l}\frac{R}{R} \\
R \\
R\end{array}$ & $\begin{array}{l}4153500-214 \\
4253200-224 \\
420324\end{array}$ & & & 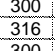 & 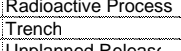 & 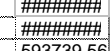 & m m\#\# & & & & $\begin{array}{l}274.3 \\
243.8 \\
\end{array}$ & $\begin{array}{l}0.3 \\
0.5 \\
\end{array}$ & & & $\begin{array}{l}\frac{82.296}{121.920} \\
-251920 \\
\end{array}$ & & & 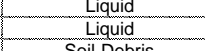 & 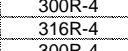 & $\begin{array}{l}\frac{30-0.24}{300-224} \\
3024\end{array}$ & 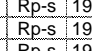 & 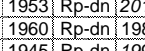 & & & & & & 20066 & $\begin{array}{l}\text { RTD } \\
\text { RTD } \\
\text { RTD }\end{array}$ & & & $\begin{array}{l}\text { 隹p-ds } \\
\text { Rp-ds }\end{array}$ & $\begin{array}{l}302 \\
302 \\
302\end{array}$ & 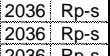 \\
\hline & $\begin{array}{l}\frac{1922300-24}{4364300-249} \\
430\end{array}$ & 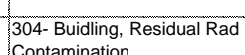 & $\frac{1}{1}$ & $\begin{array}{l}\frac{300}{300} \\
300\end{array}$ & 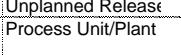 & $\begin{array}{ll}553373029.269 & \end{array}$ & 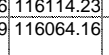 & & & $\begin{array}{l}\text { polyogon } \\
\text { poyygon }\end{array}$ & & & & & 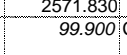 & chemicals & & $\begin{array}{l}\text { Soliobobis } \\
\text { Cement }\end{array}$ & $\begin{array}{l}300 R-4 \\
3008-4\end{array}$ & $\begin{array}{l}\frac{300-24}{300-249} \\
3\end{array}$ & $\begin{array}{l}\text { RPp. } 19 \\
\text { Rp-s } 19\end{array}$ & 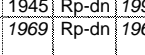 & & & & & & 2006 & $\begin{array}{l}\text { RTD } \\
\text { RTD }\end{array}$ & & & $\begin{array}{l}\text { Rppds } \\
\text { Rp-ds }\end{array}$ & $\begin{array}{l}30 \frac{2}{30} \\
302\end{array}$ & $\begin{array}{l}2036 \text { PR.S } \\
\text { 2034. }\end{array}$ \\
\hline$\frac{R}{R}$ & $\frac{1923300-25}{43636030-251}$ & & & $\begin{array}{l}300 \\
300 \\
300\end{array}$ & 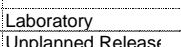 & 594247.44 & 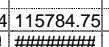 & & & point & $\begin{array}{l}71.5 \\
300 \\
300\end{array}$ & $\frac{61.9}{250}$ & 13.7 & & $\begin{array}{l}4422.510 \\
505000\end{array}$ & & $\frac{4}{4}$ & $\begin{array}{l}\text { Soil-Debris } \\
\text { iguid/osil-Debis }\end{array}$ & $\begin{array}{l}3000-4 \\
3008-4\end{array}$ & $\begin{array}{l}300-25 \\
30-251 \\
3025\end{array}$ & $\begin{array}{l}\text { Rpp.s } 19 \\
\text { Rns } 19\end{array}$ & $\begin{array}{l}1966 \text { Rp-dn 20C } \\
1943 \text { R-d } 1996\end{array}$ & & & & & & 2005 & RTD & & & $\begin{array}{l}\text { Rp-ds } \\
\text { Rpods }\end{array}$ & $\begin{array}{l}\frac{302}{302} \\
302\end{array}$ & 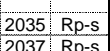 \\
\hline $\begin{array}{l}\frac{R}{R} \\
R \\
\end{array}$ & 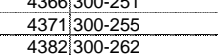 & & & $\begin{array}{l}300 \\
300 \\
300\end{array}$ & 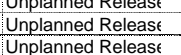 & 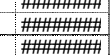 & m & & & & $\begin{array}{l}3.0 \\
23.0\end{array}$ & $\begin{array}{l}20.0 \\
20.0\end{array}$ & & & $\begin{array}{l}\text { rave.000 } \\
460.000 \\
0.999\end{array}$ & & $\frac{4}{4}$ & 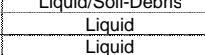 & 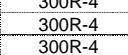 & $\begin{array}{l}300-25 \\
\text { 30-255 } \\
302-262\end{array}$ & 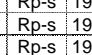 & 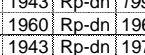 & & & & & & 2007 & $\begin{array}{l}\text { RTD } \\
\text { RT } \\
R T D\end{array}$ & & & $\begin{array}{l}\text { Rpo-ds } \\
\text { Rppods } \\
\text { Rp.ds }\end{array}$ & $\begin{array}{l}302 \\
302 \\
302\end{array}$ & 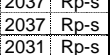 \\
\hline$\frac{R}{R}$ & 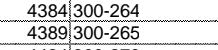 & 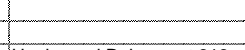 & 1 & $\frac{300}{300}$ & $\begin{array}{l}\text { LLaboratory } \\
\text { Radioactive Process }\end{array}$ & 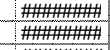 & 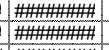 & & & & $\begin{array}{l}70.0 \\
350.0\end{array}$ & $\begin{array}{l}40.0 \\
1.0 \\
\end{array}$ & & & $\begin{array}{l}2880.000 \\
350.000 \\
\end{array}$ & & $\frac{4}{4}$ & $\begin{array}{l}\text { Soli-ibebiss } \\
\text { Liquid }\end{array}$ & $\begin{array}{l}\frac{30 P R-4}{300 R-4} \\
30\end{array}$ & $\begin{array}{l}300-264 \\
300-265 \\
3\end{array}$ & $\begin{array}{l}\text { Rpps } 19 \\
\text { Rp-s } 19\end{array}$ & & & & & & & $\frac{2005}{2005}$ & $\frac{R T D}{R T D}$ & & & 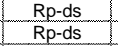 & $\begin{array}{l}302 \\
302 \\
302\end{array}$ & \\
\hline & & $\begin{array}{l}\text { Unnplanned Release a t } 313 \\
\text { Bulding }\end{array}$ & & & Unplanned Release & & - & & & & & & & & 0.9995 & & & Liquid & $300 R-4$ & $300-270$ & Rpp.S 19 & 1969 G-dn 196 & & & & & & 2006 & RTD & & & Rpods & 302 & 2036 Rp-s \\
\hline $\begin{array}{l}\frac{R}{R} \\
R\end{array}$ & $\begin{array}{l}\frac{19273030-28}{1926300-33} \\
\end{array}$ & & $\frac{1}{1}$ & $\begin{array}{l}300 \\
300 \\
300\end{array}$ & $\begin{array}{l}\text { UUpplanned Releast } \\
\text { Unplanned Releass }\end{array}$ & $\begin{array}{l}593926.6919 \\
59397.44\end{array}$ & 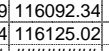 & & & $\begin{array}{l}\text { line } \\
\text { polygon }\end{array}$ & $\begin{array}{l}168.0 \\
15.8 \\
\end{array}$ & $\begin{array}{l}6.5 \\
48.8 \\
\end{array}$ & & & $\frac{1055.000}{56458505}$ & & $\frac{4}{4}$ & 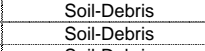 & $\begin{array}{l}\frac{3000-4}{300 R-4} \\
3\end{array}$ & $\begin{array}{l}300-28 \\
300-33 \\
\end{array}$ & 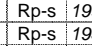 & 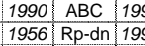 & & & & & & 2009 & $\begin{array}{l}\text { RTD } \\
\text { RTD }\end{array}$ & & & $\begin{array}{l}\frac{R}{R p-d s} \\
\text { Rppds }\end{array}$ & $\begin{array}{l}\frac{302}{30} 2 \\
302\end{array}$ & 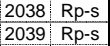 \\
\hline & & 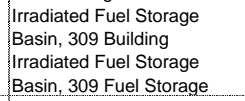 & & & & & & & & & & & & & & & & & & & & & & & & & & & & & & & & \\
\hline & 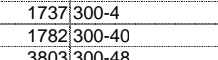 & & & $\begin{array}{l}300 \\
300 \\
302\end{array}$ & 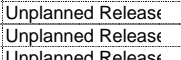 & 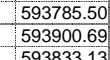 & 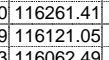 & & & $\begin{array}{l}\frac{P \text { poyyon }}{\text { point }} \\
\text { pon }\end{array}$ & $\begin{array}{l}19.5 \\
147\end{array}$ & 21.3 & & & $\begin{array}{l}415.000 \\
0.030 \\
10.032 \\
\end{array}$ & & $\frac{4}{4}$ & $\begin{array}{l}\text { Liquid/losoli-iedobis } \\
\text { Liquid }\end{array}$ & $\begin{array}{l}300 R-4 \\
300 R-4\end{array}$ & $\begin{array}{l}\frac{30-4}{300-40} \\
30\end{array}$ & $\begin{array}{l}\text { Rpp-5 } 19 \\
\text { Rp-5 } 19\end{array}$ & 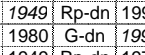 & & & & & & 2009 & $\begin{array}{l}\text { RTD } \\
\text { RTD }\end{array}$ & & & $\begin{array}{l}\frac{R p-d s}{\text { Rp.ds }} \\
\text { Rpd }\end{array}$ & & $\begin{array}{l}20399 \text { Rp-s } \\
2030.5\end{array}$ \\
\hline $\mathrm{R}$ & 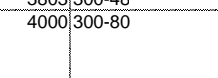 & 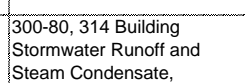 & & & & & 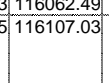 & & & $\begin{array}{l}\text { Poyygon } \\
\text { poyygan }\end{array}$ & $\begin{array}{r}1.47 \\
1.2192 \\
\end{array}$ & $\begin{array}{r}.87 \\
1.2192 \\
\end{array}$ & & & & Stormwater Runoff & & $\begin{array}{l}\text { Llaud } \\
\text { Liquid }\end{array}$ & $\begin{array}{l}\frac{300 R-4}{300 R-4} \\
3\end{array}$ & 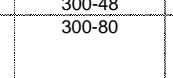 & & & & & & & & $\frac{2010}{2010}$ & $\begin{array}{l}\text { RTD } \\
\text { RTD }\end{array}$ & & & 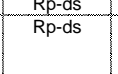 & & 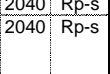 \\
\hline $\mathrm{R}$ & $1052303-K_{-}$CWS & 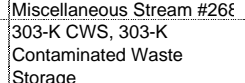 & 1 & 300 & Storage & & 6116112.54 & & & Polygon & 24.0792 & 28.6512 & 4.1148 & & & & & Soli and Liquid & 300R-4 & 303-K_ws & Rp-s 19 & & & & & & & 2002 & RTD & & & Rp-ds & 302 & 2032 Rp.s \\
\hline
\end{tabular}


Geographic and Operational Site Parameters for Waste Sites To Be Simulated in the 2004 Composite Analysis

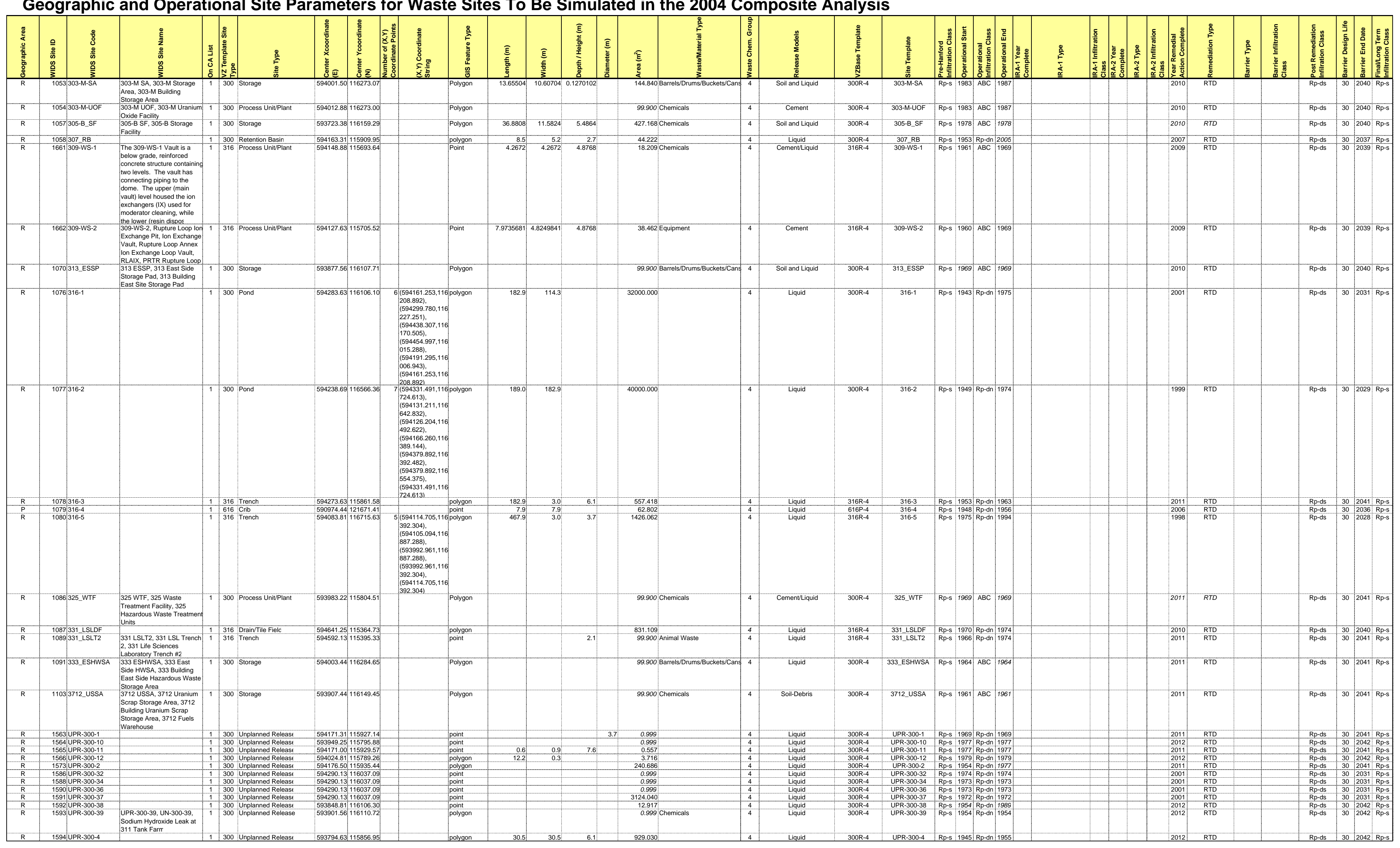


Geographic and Operational Site Parameters for Waste Sites To Be Simulated in the 2004 Composite Analysis

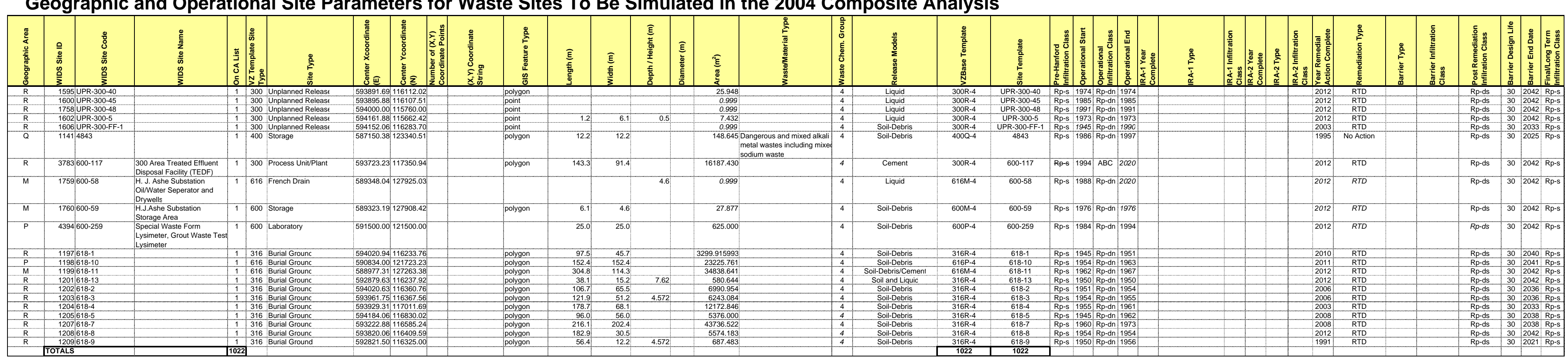




\section{Distribution}

No. of

Copies

\section{ONSITE}

2 DOE Office of River Protection

R. M. Yasek

R. W. Lober

9 DOE Richland Operations Office

B. L. Charboneau A6-33

B. L. Foley A6-38

J. P. Hanson A5-13

R. D. Hildebrand A6-38

J. G. Morse A6-38

K. M. Thompson A6-38

S. H. Wisness A3-04

DOE Public Reading Room (2) H2-53

5 Bechtel Hanford Inc.

P. G. Doctor

H9-01

K. R. Fecht

K. A. Gano

J. K. Linville

S. G. Weiss

9 CH2M HILL Hanford Group, Inc.

F. J. Anderson

E6-35

A. J. Knepp

M. N. Jarayssi

F. M. Mann

W. J. McMahon

C. W. Miller

D. A. Myers

C. D. Wittreich

M. I. Wood

\section{Fluor Federal Services}

R. Khaleel

R. J. Puigh
No. of

Copies

8 Fluor Hanford, Inc.

J. V. Borghese

E6-35

F. M. Coony

E6-35

B. H. Ford

E6-35

T. W. Fogwell

E6-35

R. Jackson

E6-35

V. J. Rohay

E6-35

L. C. Swanson

E6-35

M. E. Todd-Robertson

E6-35

Stoller

R. G. McCain

B2-62

50 Pacific Northwest National Laboratory
R. L. Aaberg
K3-54

C. Arimescu

K6-04

M. P. Bergeron

K9-36

B. N. Bjornstad

K6-81

R. W. Bryce

E6-35

A. L. Bunn

K6-85

K. J. Cantrell

K6-81

Y. J. Chien

K6-81

R. L. Dirkes

K6-75

J. L. Downs

K6-85

D. W. Engle

K5-12

P. W. Eslinger

K6-04

M. J. Fayer

K9-33

E. J. Freeman

K9-36

M. D. Freshley

K9-33

G. W. Gee

K9-33

T. J Gilmore

K6-81

D. G. Horton

K6-81

C. T. Kincaid

K9-33

G. V. Last (5)

K6-81

C. A. LoPresti

K5-12

W. J. Martin

K6-81

T. B. Miley

K6-04

C. J. Murray

K6-81 
No. of

Copies

B. A. Napier

W. E. Nichols

G. W. Patton

J. V. Ramsdell, Jr.

S. P. Reidel

M. C. Richmond

R. G. Riley

M. L. Rockhold

R. J. Serne
No. of

Copies

K3-54

K9-33

K6-75

K3-54

K6-81

K9-33

K6-96

K9-36

P7-22
D. L. Strenge

M. B. Triplett

P. D. Thorne (5)

A. L. Ward

M. D. White

M. D. Williams

S. K. Wurstner

S. B. Yabusaki

Hanford Technical Library (2)
K3-54

K6-04

K9-33

K9-33

K9-36

K9-36

K9-36

K9-36

H2-53

Distr.2 